\title{
Article
}

\section{Toxic Metals (As, Cd, Ni, Pb) Impact in the Most Common Medicinal Plant (Mentha piperita)}

\author{
Cristina Dinu ${ }^{1,+(\mathbb{D})}$, Stefania Gheorghe ${ }^{1, *(\mathbb{D})}$, Anda Gabriela Tenea ${ }^{1,2,+}$, Catalina Stoica ${ }^{1}$, \\ Gabriela-Geanina Vasile ${ }^{1}$ (D), Roxana Luisa Popescu ${ }^{3}$, Ecaterina Anca Serban ${ }^{1}$ and Luoana Florentina Pascu ${ }^{1}$ \\ 1 National Research and Development Institute for Industrial Ecology ECOIND Bucharest, 71-73 Drumul \\ Podul Dambovitei Street, 060652 Bucharest, Romania; cristina.dinu@incdecoind.ro (C.D.); \\ anda.tenea@incdecoind.ro (A.G.T.); catalina.stoica@incdecoind.ro (C.S.); \\ gabriela.vasile@incdecoind.ro (G.-G.V.); anca.serban@incdecoind.ro (E.A.S.); ecoind@incdecoind.ro (L.F.P.) \\ 2 Science Faculty, Chemistry Department, University of Craiova, 107i Bucharest Street, \\ 200478 Craiova, Romania \\ 3 National Research and Development Institute for Industrial Ecology ECOIND Ramnicu Valcea Branch, \\ 182 Stirbei Voda Street, 240588 Ramnicu Valcea, Romania; roxana.popescu@incdecoind.ro \\ * Correspondence: stefania.gheorghe@incdecoind.ro \\ + Authors with equal contribution.
}

\section{check for} updates

Citation: Dinu, C.; Gheorghe, S.; Tenea, A.G.; Stoica, C.; Vasile, G.-G.; Popescu, R.L.; Serban, E.A.; Pascu, L.F. Toxic Metals (As, Cd, Ni, Pb) Impact in the Most Common Medicinal Plant (Mentha piperita). Int J. Environ. Res. Public Health 2021, 18, 3904. https://doi.org/10.3390/ ijerph18083904

Academic Editor: María Teresa Barral Silva

Received: 12 March 2021

Accepted: 6 April 2021

Published: 8 April 2021

Publisher's Note: MDPI stays neutral with regard to jurisdictional claims in published maps and institutional affiliations.

Copyright: (c) 2021 by the authors. Licensee MDPI, Basel, Switzerland. This article is an open access article distributed under the terms and conditions of the Creative Commons Attribution (CC BY) license (https:// creativecommons.org/licenses/by/ $4.0 /)$.

\begin{abstract}
This study aimed to evaluate the behavior of Mentha piperita under $\mathrm{Cd}, \mathrm{Pb}, \mathrm{Ni}$, and As soil contamination and their transfer from soil in plants as well as translocation in the roots/stems/leaves system compared with a control without metal addition. The mint seedlings were exposed for a threemonth period using two metal mixtures in the same concentrations such as AsCd and AsCdNiPb (23.7 mg/ kg As, $5 \mathrm{mg} / \mathrm{kg} \mathrm{Cd}, 136 \mathrm{mg} / \mathrm{kg} \mathrm{Ni}$, and $95 \mathrm{mg} / \mathrm{kg} \mathrm{Pb}$ ). The results of metal concentration in plants showed that $\mathrm{Cd}, \mathrm{Ni}$, and $\mathrm{Pb}$ were accumulated in different parts of the plant, except for As. In plants organs, the order of metal accumulation was roots $>$ stems $>$ leaves. No significant impact on the growth, development, and chlorophyll content compared to the control was observed in the first month of exposure. After three months of exposure, phytotoxic effects occurred. Generally, the transfer coefficients and translocation factors values were less than 1, indicating that Mentha piperita immobilized the metals in root. The laboratory experiments highlighted that for a short period of time, Mentha piperita has the capacity to stabilize the metals at the root level and was a metal-tolerant plant when using a garden rich-substrate.
\end{abstract}

Keywords: Mentha piperita; metals; translocation

\section{Introduction}

The presence of metals in the environment represents a concern for the safety of the food and implicitly for human life. In natural systems, heavy metals come from rocks, ores, volcanoes, and from the release of metals during the weather that leads to soil formation [1]. A very acute problem occurs when the heavy metals concentration increases significantly in certain ecosystems due to anthropogenic activities [2-7].

Heavy metals interact strongly with the soil matrix and may become mobile as a result of changing environmental conditions [8]. Considering the fact that the soil represents a living system consisting in various organisms including plants, an increase of contaminants can adversely affect the normal growth or development of plants and finally the safety of plant products. The plant are soil-dependent photosynthetic organisms, which have the ability to accumulate trace elements, especially heavy metals, due to their ability to tolerate potentially toxic ions in the environment [9]. Human and animal diets, as well as health care programs, are based on various vegetable foods and medicinal herbs, leading to the bio magnification process of some accumulative contaminants in the final trophic chain. From the ancient times and likewise nowadays, the medicinal plants are the primary source 
for prevention, improving of symptoms, and the treatment in various diseases. According to the World Health Organization (WHO), approximately $80 \%$ of the population living in the outlying areas use only herbs to treat multiple diseases $[10,11]$. When using herbs in the treatment of certain conditions, it should be noted that in addition to the pharmacological effect, they can be toxic if they contain toxic contaminants such as pesticides or heavy metals. It is considered that prolonged treatment with plants with a heavy metal content such as: lead $(\mathrm{Pb})$, cadmium $(\mathrm{Cd})$, zinc $(\mathrm{Zn})$, and nickel $(\mathrm{Ni})$ above the maximum allowed limit can cause severe health problems, including dermatitis, poisoning, organ dysfunctions, cancer, mental retardation, damage to nervous system, anemia, etc. [12]. In addition, plants can be easily contaminated with heavy metals during both cultivation and processing [13].

According to the WHO, the maximum allowed limits sets in medicinal herbs are $0.3 \mathrm{mg} / \mathrm{kg}$ dry weight (d.w.) for Cd, $1 \mathrm{mg} / \mathrm{kg} \mathrm{d.w}$ for arsenic (As), and $10 \mathrm{mg} / \mathrm{kg}$ d.w. for $\mathrm{Pb}[14,15]$. In addition, WHO documents specified permissible limits for As such as $5 \mathrm{mg} / \mathrm{kg}$ d.w. in Canada, $2 \mathrm{mg} / \mathrm{kg}$ d.w. in China, and $4 \mathrm{mg} / \mathrm{kg}$ d.w. in Thailand [16]. The same organization recommended a maximum limit of $10 \mu \mathrm{g} / \mathrm{L}$ of As in the drinking water, which is a very small concentration that can induce toxicity [17]. Moreover, European Commission Regulation no. 1881/2006 for foodstuff contamination set for $\mathrm{Pb} 0.1 \mathrm{mg} / \mathrm{kg}$ d.w. and Cd $0.2 \mathrm{mg} / \mathrm{kg} \mathrm{d.w.} \mathrm{in} \mathrm{fresh} \mathrm{herbs} \mathrm{[18].}$

Depending on their role in the organism body, heavy metals can be essential and non-essential. Essential metals or micronutrients, such as $\mathrm{Cr}, \mathrm{Co}, \mathrm{Cu}, \mathrm{Mn}, \mathrm{Mo}, \mathrm{Ni}, \mathrm{Fe}$, $\mathrm{Se}$, and $\mathrm{Zn}$ are required for optimal functioning of biological and biochemical processes, including humans. Non-essential metals such as $\mathrm{As}, \mathrm{Cd}, \mathrm{Hg}$, and $\mathrm{Pb}$ have no known biological function. Heavy metals are not biodegradable, which is why they can be toxic even at low concentrations, representing a serious threat to both the environment and human health [19].

Lead is a very common contaminant in industrial wastewater being used in many industrial applications such as the manufacturing of batteries, pigment for paint, photographic materials, auto industry, etc. [20,21]. In agriculture, Pb limits crop productivity [22] and could increase the production of reactive oxygen species inducing the oxidative stress in plants [23]. Lead was detected in different market products (pharmacy, herbal store, traditional market, supermarket) ranging from 0.03 to $1.11 \mathrm{mg} / \mathrm{kg}$, but also $\mathrm{Cd}(0.18$ to $0.28 \mathrm{mg} / \mathrm{kg}$ ) and Ni (1.01 to $1.96 \mathrm{mg} / \mathrm{kg}$ ) according to Rubio et al. [24].

Cadmium is generally derived from human activities (mining, metallurgy, waste combustion, and abusive pesticides and fertilizer use). It is very toxic for aquatic and terrestrial organisms, which has been well studied $[25,26]$. Increased concentrations of $\mathrm{Cd}$ in plants can lead to reduced photosynthesis, decreased water absorption, and lower nutrient uptake. Plants grown in soils containing high amounts of $\mathrm{Cd}$ are affected by growth inhibition, root drying, and then plant death [25,27].

Another toxic metal is arsenic derived by industrial activities or from the use of fertilizers. As occurs most commonly in the environment in trivalent and pentavalent oxidation states, which are found in both organic and inorganic compounds. Arsenate $\left(\mathrm{AsO}_{4}{ }^{3-}\right)$ and arsenite $\left(\mathrm{AsO}_{3}{ }^{3-}\right)$ are the most soluble inorganic forms found in water and soil $[19,28]$. The impact on the environment is associated with the high mobility of this element [29]. The concentrations of different forms of arsenic in soil, as well as its mobility in the water-soil-plant system are affected by the physical, chemical, and biochemical properties of the soil such as redox potential, $\mathrm{pH}$, texture, presence of changeable ions, biological activity, and organic matter content [30,31].

Nickel is an essential element for the growth and development of plants mainly for the activation of enzymes such as urea and glyoxalase. Nickel is also important in the germination process of seeds, in photosynthesis and in the metabolism of nitrogen [32], but it can become toxic for plants at high concentrations (more than 10 to $1000 \mathrm{mg} / \mathrm{kg} \mathrm{d} . \mathrm{w}$. depend on plant sensitivity) [33].

In Romania, different sites contaminated with toxic metals were reported, mainly as a result of anthropogenic sources. Different types of soils and sediments collected from 
mining sites (Baia Mare (As, Cd) and Certej (As, $\mathrm{Cd}, \mathrm{Ni}, \mathrm{Pb})$ ), or from areas adjacent to metallurgical activities, such as Copsa Mica ( $\mathrm{Cd}, \mathrm{Cu}, \mathrm{Pb}, \mathrm{Zn}$ ) or Zlatna (As, Cu, Pb, Zn) were highly contaminated [6,34-36].

In mining areas, where surface mining is either in operation or closed, the amounts of toxic metals discharged into the environment can be dangerously elevated. Thus, by leaching the contaminated areas with rainwater, both surface waters and sediments can be polluted. As a result, aquatic and riparian flora could be affected. Dinu et al. reported concentrations of metals ranging between 5.5 and $121 \mathrm{mg} \mathrm{As} / \mathrm{kg} ; 1.2$ and $11.4 \mathrm{mg} \mathrm{Cd} / \mathrm{kg}$; 26 and $610 \mathrm{mg} \mathrm{Ni} / \mathrm{kg} ; 50$ and $888 \mathrm{mg} \mathrm{Pb} / \mathrm{kg}$ in soil samples collected from an area situated in Romania [37].

Since they have the capacity to concentrate in soil, heavy metals are easily transferred along the trophic chain. There are various studies on heavy metals accumulation in plants cultivated in contaminated soil, especially using plants with economic interest such as crop plants, food fresh plants, medicinal, or aromatic plants $[15,26,38,39]$.

The phyto-pharmaceutical products based on Geranium sps., Mentha sps, Ocinum sps., Matricaria sps., Salvia sps., Lavandula sps., and Rosmarinus sps. are widespread, and the plants are based from organic crops [39-41]. Janvi Pandey reported that certain medicinal plants are very good $\mathrm{Cd}, \mathrm{Pb}, \mathrm{Zn}$, and $\mathrm{Cr}$ accumulators [39]. Since Mentha sp. medicinal or aromatic products are widely spread, the Mentha plants growing in metal contaminated site could affect the human health safety.

Various metals concentration such as $\mathrm{Pb} 0.65 \pm 0.71 \mathrm{mg} / \mathrm{kg}$ (Spain), 1.83 to $2.58 \mathrm{mg} / \mathrm{kg}$ (Bulgaria), $2.41 \mathrm{mg} / \mathrm{kg}$ (Poland); Cd $0.22 \pm 0.13 \mathrm{mg} / \mathrm{kg}$ (Spain), $0.09 \mathrm{mg} / \mathrm{kg}$ (Poland), $0.369 \mathrm{mg} / \mathrm{kg}$ (India), 0.022 to $0.12 \mathrm{mg} / \mathrm{kg}$ (Bulgaria), $0.02 \mathrm{mg} / \mathrm{kg}$ (Turkey); and Ni $4.84 \pm 1.13 \mathrm{mg} / \mathrm{kg}$ (Spain), $2.99 \mathrm{mg} / \mathrm{kg}$ (Poland), $0.002 \mathrm{mg} / \mathrm{kg}$ (India), $3.52 \mathrm{mg} / \mathrm{kg}$ (Turkey) were detected in Mentha piperita herbal tea as reported by Rubio et al. [24].

Mentha piperita is part of the Lamiaceae family along with other aromatic plants used in medicinal products, foods, drinks, teas, cosmetically products, etc. Several species of mint have been described, but not all of them have therapeutic properties. The mint species, which are recognized to have medicinal properties, are Mentha aquatica (water mint), Mentha viridis or Mentha spicata (sweet mint), and a hybrid of the two species: Mentha piperita. All species of mint develop very well in cool places, partially covered by the sun. The growth of the plant is very fast. The plant has a roots system from which appear stems up to $40-130 \mathrm{~cm}$ high. The plant is multiplied by cuttings or stolons. The stems are red-purple and very branched, and the leaves are elongated-oval in shape, light green in color, and have serrated edges. In Europe, peppermint came into medicinal use for nausea, vomiting, and gastrointestinal disorders in the mid-eighteenth century. Extracts from Mentha piperita leaves have therapeutic efficiency in arsenic toxicity amelioration in Swiss Albino mice. It seems that this plant decreases the lipid peroxidation, scavenging free radicals, reducing genotoxicity, and exhibiting the hepatic effects caused by the arsenic contamination [28]. In addition to medicinal properties, mint is also known for insecticidal properties against mosquitoes, wasps, and beetles [42,43].

Moreover, in the last five years, more than 120 applicative experiments on Mentha species were performed in research areas such as plant science, food science, pharmacology, and biotechnology, in environmental sciences and ecology (https:/ / webofknowledge.com, accessed on 30 July 2020).

This study aimed to evaluate the effect of toxic metals $\mathrm{Cd}, \mathrm{Ni}, \mathrm{Pb}$, and As on Mentha piperita grown in an enriched soil in laboratory conditions by simulating a soil polluted by mining activities. The experiment was carried out over a period of three months, in order to assess the ability of Mentha piperita to accumulate the metals from the soil and to transfer them from the roots to the aerial parts (stem, leaves). 


\section{Materials and Methods}

\subsection{Plants and Soil Characteristics}

Ten uniform mint (Mentha piperita) seedlings (from local agriculture) with initial size of about $20 \pm 5 \mathrm{~cm}$ were placed in $5000 \mathrm{~g}$ soil for each control and polluted soil in different flower pots under laboratory conditions.

The soil control was a universal substrate enriched with nutritive elements provided by local producers, consisting of peat and humus for garden plants cultivation. An initial physical and chemical characterization of the control soil before the planting procedure was done.

The soil enrichment solutions were prepared using standard solutions of $\mathrm{Cd}, \mathrm{Ni}, \mathrm{Pb}$, and $\mathrm{As}$ in $5 \% \mathrm{HNO}_{3}$ dissolved in ultrapure water obtained using an Elix Technology Inside with a Quantum ICP Polishing Cartridge (Milli-Q, Molsteim, France) system, with a resistivity of at least $18 \mathrm{M} \Omega \cdot \mathrm{cm}$ (equivalent to a conductivity of less than $5.6 \times 10^{-5} \mathrm{mS} \mathrm{cm}^{-1}$ ).

The soil treatment with metal solutions was performed at the beginning of the experiment (in May 2019), by watering, one week after seeding of the plants.

\subsection{Experiment Characteristics}

The laboratory soil contamination simulates the characteristics of industrial polluted soil by mining activities.

To reach the intervention threshold values for sensitive soils according to the Romanian legislation MAPPM (1997) for analyzed elements (As, Cd, Ni, Pb), the soils were spiked with different solutions. Three different experiments were noted as $M$ (the control soil with no metals addition); $A s C d$ (polluted soil with $23.7 \mathrm{mg} / \mathrm{kg}$ As and $5 \mathrm{mg} / \mathrm{kg} \mathrm{Cd}$ ); and $A s C d N i P b$ (polluted soil with $23.7 \mathrm{mg} / \mathrm{kg} \mathrm{As}, 5 \mathrm{mg} / \mathrm{kg} \mathrm{Cd}, 136 \mathrm{mg} / \mathrm{kg} \mathrm{Ni}$ and $95 \mathrm{mg} / \mathrm{kg} \mathrm{Pb}$ ).

The concentrations and mixture of toxic metals were established considering the real contamination circumstances prevailing in Romania to estimate the overall effects of metals on the plant development.

The enrichments were added taking into account the initial concentration of elements detected in the used substrate (Table 1). As, $\mathrm{Cd}, \mathrm{Ni}$, and $\mathrm{Pb}$ values in the control experiment (M) indicate normal values for soil quality [44].

Table 1. The results of metal concentrations (average \pm SD) detected in control soil.

\begin{tabular}{ccccc}
\hline & $\begin{array}{c}\text { Control Soil (M) } \\
\pm \text { SD } \\
\text { Metals }\end{array}$ & \multicolumn{2}{c}{ Reference Values for Soils with Sensitive Uses (mg/kg d.w.) * } \\
\cline { 2 - 4 } & (mg/kg d.w.) & Normal Value & $\begin{array}{c}\text { Alert } \\
\text { Threshold }\end{array}$ & $\begin{array}{c}\text { Intervention } \\
\text { Threshold }\end{array}$ \\
\hline $\mathrm{As}$ & $1.29 \pm 0.33$ & 5 & 15 & 25 \\
$\mathrm{Cd}$ & $<0.08^{* *}$ & 1 & 3 & 5 \\
$\mathrm{Ni}$ & $13.4 \pm 0.12$ & 20 & 75 & 150 \\
$\mathrm{~Pb}$ & $4.8 \pm 0.56$ & 20 & 50 & 100 \\
\hline
\end{tabular}

Note: * MAPPM Order 756/1997; SD—Standard Deviation $(n=6) ;{ }^{* *}$ value lower than method quantification limit.

The batch of experiments was performed in a laboratory using an acclimatization system $\left(23 \pm 2{ }^{\circ} \mathrm{C}\right)$ under natural light $(12 \mathrm{~h}$ per day and night, day light intensity was 421 to 2411 lux) and relative humidity of about $23 \%$. The pots were rotated and were mixed with a weekly frequency. To prevent the leakage of nutrients and metals from the substrate, plastic trays were used under each pot. The exposure period was about three months (May, June, and July). The plants were soaked with free chlorine tap water. An initial characterization of water before use was done. The watering was performed about three times per week in order to ensure a constant soil humidity for about $60 \%$ of the maximum moisture holding capacity of used soil. 


\subsection{Sampling of Soil and Chemical Analyses}

The metals $(\mathrm{Cd}, \mathrm{Ni}, \mathrm{Pb}, \mathrm{As})$ content was monthly detected both from soil (control soil/polluted soil) and plants (control/exposed plants), respectively. The soil samples for metal content detection were collected from two depths as follows: $0-6 \mathrm{~cm}$ and $6-12 \mathrm{~cm}$. The depths were in accordance with the elongation of the peppermint plant roots. Up to $12 \mathrm{~cm}$, the root maturation zone starts to develop; around this depth, the primary roots acquire lateral or hair roots.

The samples were air dried, homogenized, and sieved for analysis of the fraction less than $150 \mu \mathrm{m}$ according to ISO 11464:2006 [45]. A Retsch RM 100 Mill (Haan, Germany), a Fritsch Analysette 3 Spartan vibratory sieve shaker (Idar, Oberstein), and a Kern ABT 220-50M analytical balance (Balingen, Germany) were used for the soil samples preparation.

Two grams of soil were digested with a mixture of nitric acid and hydrochloric acid $(1: 3 v / v)$ and then mineralized in an open system (Falc ceramic-glass heater, Treviglio, Italy) until the organic matter was mineralized. The mixture was filtered and washed with analytical pure water according to ISO 11466 [46] and to Vasile et al. [47]. The samples were analyzed for the metal content by inductive coupled plasma optical emission spectrometry (ICP-EOS, Avio 500 Perkin Elmer Spectrometer, Waltham, MA, USA).

The following chemical parameters were additionally analyzed using standardized methods: pH-SR EN ISO 10523:2012; conductivity—SR ISO 11265 + A1:1998, potassium (K)—SR EN 16170:2017, total nitrogen $\left(\mathrm{N}_{\text {total }}\right)$ - SR ISO 11261:2000; total phosphorus $\left(\mathrm{P}_{\text {total }}\right)$-STAS 7184/14-79; total organic carbon (TOC)—SR EN 15936:2013, humus and total carbon $\left(C_{\text {total }}\right)$ SR ISO 10694:1998; organic chlorinate pesticides (SR ISO 10382:2007) and triazine pesticides (ISO 11264:2005(E)).

The results validity of nutrients, metals, and $\mathrm{pH}$ determinations in soil were verified using a sewage sludge Certified reference material VHG-SL1 (LGC Standards, Manchester, $\mathrm{NH}$, USA).

For the results validity of total carbon, the followed Certified reference materials were used: Soil Standard Silty OAS (Elemental Microanalysis Ltd., Okehampton, UK) and harbor sediments. AGLAE 19M 9.2 (AGLAE Association, Giberville, France). For TOC, we used Soil Standard Clay B2184 (Elemental Microanalysis Ltd., Okehampton, UK).

\subsection{Sampling of Plants and Metal Analyses}

The harvested mint plants used for metal detection were washed firstly with tap water and secondly with distilled water. The plants were separated on roots, leaves, and stems and dried using a Lyophilizer Christ Alpha 1-2 LD (Martin Christ GmbH, Osterode, Germany) at $-55^{\circ} \mathrm{C}$. After the drying procedure, the mint samples were thinly milled. About 0.2 to $0.5 \mathrm{~g}$ was weighed for metal content analysis. The mint samples were processed with $10 \mathrm{~mL}$ of $\mathrm{HNO}_{3}$ and $3 \mathrm{~mL}$ of $\mathrm{H}_{2} \mathrm{O}_{2}$ for $24 \mathrm{~h}$ at room temperature in order to mineralize organic matter (cold mineralization). The final mineralization at $180^{\circ} \mathrm{C}(1800 \mathrm{~W})$ for $15 \mathrm{~min}$ was performed using a Milestone Ethos Up microwave digester (Sorisole, Italy). The extract was filled up to a $25 \mathrm{~mL}$ volumetric flask, and the metal concentration was detected.

The content of metals in plant extracts was controlled using a simultaneous determination method with an ICP-EOS technique. The performance parameters of the applied method (detection limit, precision, and uncertainty) are presented in Table 2.

To assure the quality and validity of results, a certified reference material consisting of trace elements (As, Cd, Cr, Cu, Ni, $\mathrm{Pb}$, and $\mathrm{Zn}$ ) in lichen powder (BCR-482, Institute for Reference Materials and Measurements, Geel, Belgium) was used. The recovery percentages for all analyzed metals varied between 95.8 and $103.7 \%$ (Table 2). 
Table 2. The performance parameters of the applied method.

\begin{tabular}{|c|c|c|c|c|c|c|}
\hline \multirow[b]{2}{*}{ Metals } & \multirow{2}{*}{$\begin{array}{l}\text { LOD, } \\
\mathrm{mg} / \mathrm{kg}\end{array}$} & \multirow{2}{*}{$\begin{array}{l}\text { Precision, } \\
\%\end{array}$} & \multirow[b]{2}{*}{ Uncertainty, \% } & \multicolumn{3}{|c|}{ BCR-482 } \\
\hline & & & & $\begin{array}{l}\text { Certified Value } \pm \\
\text { Uncertainty, mg/kg }\end{array}$ & $\begin{array}{c}\text { Determined Value } \pm \\
\text { Uncertainty, mg/kg }\end{array}$ & Recovery, \% \\
\hline As & 0.25 & 7.50 & 15.3 & $0.85 \pm 0.07$ & $0.88 \pm 0.13$ & 103.5 \\
\hline $\mathrm{Cd}$ & 0.02 & 5.65 & 12.5 & $0.56 \pm 0.02$ & $0.54 \pm 0.07$ & 96.43 \\
\hline $\mathrm{Cr}$ & 0.02 & 4.55 & 13.1 & $4.12 \pm 0.15$ & $4.23 \pm 0.55$ & 102.7 \\
\hline $\mathrm{Cu}$ & 0.02 & 5.30 & 12.6 & $7.03 \pm 0.19$ & $6.94 \pm 0.87$ & 98.72 \\
\hline $\mathrm{Ni}$ & 0.04 & 4.80 & 12.7 & $2.47 \pm 0.07$ & $2.56 \pm 0.33$ & 103.7 \\
\hline $\mathrm{Pb}$ & 0.50 & 5.70 & 14.6 & $40.9 \pm 1.4$ & $39.6 \pm 5.8$ & 96.82 \\
\hline $\mathrm{Zn}$ & 0.03 & 5.35 & 12.7 & $100.6 \pm 2.2$ & $96.4 \pm 12.2$ & 95.81 \\
\hline
\end{tabular}

\subsection{Biometrical Measurements and Chlorophyll Detection}

The biometrical measurements and chlorophyll detection were done only after one month of Mentha piperita plants metals exposure. The stem elongation, the number of leaves, and their length, width, and wet weight were analyzed. Due to the phytotoxic effects observed at the final of the test, only stems were measured.

The chlorophyll pigments (chlorophyll $a$ and chlorophyll $b$ ) of mint samples were analyzed considering the methods described in Lichtenthaler and Buschmann [48], and Krishnan et al. [49]. The chlorophyll from the leaves samples was extracted in $80 \%$ acetone at 1:2.5 [mass $(\mathrm{g}) /$ volume $(\mathrm{mL})]$ ratio. The leaves were cut into $1-2 \mathrm{~cm}$ pieces and homogenized. The leaves tissues were incubated in $80 \%$ buffered acetone on a mixing tube revolver Rotator D6050 (neoLabLine, Heidelgerg, Germany) for $12 \mathrm{~h}$ at $4{ }^{\circ} \mathrm{C}$.

The extract was centrifuged for $3 \mathrm{~min}$ at $2545 \times g$ (centrifuge 5702R, Eppendorf AG Hamburg, Germany), and subsequently, the absorbance at $662 \mathrm{~nm}$ and $645 \mathrm{~nm}$ was measured using UV-VIS spectrometer Specord 205BU (Analytik Jena, Jena, Germany). Chlorophyll concentrations were calculated using the following equations:

$$
\begin{aligned}
& \text { Chlorophyll concentration a }(\mathrm{mg} / \mathrm{mL})=\left(12.25 \times A_{662 \mathrm{~nm}}\right)-\left(2.79 \times A_{645 \mathrm{~nm}}\right) \\
& \text { Chlorophyll concentration } \mathrm{b}(\mathrm{mg} / \mathrm{mL})=\left(21.5 \times A_{645 \mathrm{~nm}}\right)-\left(5.1 \times A_{662 \mathrm{~nm}}\right) .
\end{aligned}
$$

The sum of the two types of chlorophyll pigments represented the total chlorophyll concentration $(\mathrm{mg} / \mathrm{mL})$.

\subsection{Data Analyses}

The results represented the average of the two separate experiments. The samples collected from each experiment were analyzed for metal detection as follows: in three replicates for soil and two replicates for plants. In addition, two replicates were performed for chlorophyll detection. The quantities of plants samples obtained after the drying process were in some cases not sufficient for three replicates.

The results were correlated and compared with control samples values and with the reference values for the soil and plant quality [14,16,44].

To evaluate the plants' ability to accumulate metals from soil and to transfer them from the root to the aerial parts (stem, leaves), the transfer coefficient (TC) or bioaccumulation factor (BCF) and the translocation factor (TF) were calculated. The TC factor was defined as the ratio between the metal concentration in the roots and its content in the soil (results express in $\mathrm{mg} / \mathrm{kg}$ ) [50]. Olowoyo et al. stated that a TC value higher than 1 suggests metals accumulation, a TC value around 1 shows that the plant was not influenced by the metal, and a TC less than 1 indicates no metal uptake [51].

The TF factor was calculated as the ratio between the metal concentration detected in the upper aerial part and the metal concentration detected in the roots [50]. In this case, the values higher than 1 indicate that the plant effectively translocate metals from the root to the aboveground plant part. 
These parameters were calculated taking into consideration the tested metals content $(\mathrm{Cd}, \mathrm{Ni}, \mathrm{Pb})$ in control and polluted samples collected in May, June, and July, except for As, which was not detected in plants.

\subsection{Statistical Analysis}

The average and standard deviation (SD) values were calculated for all metal concentrations in soil $(n=6)$ and plant $(n=4)$, biometrical indicators $(n=12)$, and chlorophyll $(n=4)$. The Pearson correlation $(r)$ was used for the correlation between experiments.

The interpretation of the obtained experimental data was performed using ANOVA ONE-WAY, depending on the value of $p$ obtained. The value of $p$ was considered insignificant for $p>0.05$ (ns), significant for $p<0.05(*)$, and very significant for $p<0.01(* *)$. Thus, the experimental data obtained for the soil depth $(0-6 \mathrm{~cm}$ and 6-12 cm) and for each organ of the plant separately (stem-root, root-leaf, stem-leaf) were interpreted. The interpretation of the data was performed for the control samples as well as for the contaminated samples.

\section{Results}

\subsection{Physical and Chemical Properties of Substrate and Watering Media}

The results of physical-chemical parameters detected from the soil control showed a conductivity of $475 \mu \mathrm{S} / \mathrm{cm}$, humus $9.3 \%, \mathrm{~K} 1872 \mathrm{mg} / \mathrm{kg}$ d.w. (dry weight), total nitrogen $\left(\mathrm{N}_{\text {total }}\right) 1.20 \%$, total phosphorus $\left(\mathrm{P}_{\text {total }}\right) 4173 \mathrm{mg} / \mathrm{kg}$ d.w., total organic carbon $\left(\mathrm{TOC}_{\text {total }}\right)$ $10 \%$, and total carbon $\left(\mathrm{C}_{\text {total }}\right) 23 \%$. The $\mathrm{pH}$ value indicated a weak acid reaction of the soil. Due to nitrogen and phosphorus content, the soil was considered a clay soil that was rich in organic matter. The soil $\mathrm{C} / \mathrm{N}$ ratio of 19.2 indicated rather mineralization than microbial immobilization, which means microbial activity in soil and the release of nitrogen, available for plant uptake.

No organic chlorinated and triazine pesticides were detected in soil. Co, $\mathrm{Cu}, \mathrm{Mn}, \mathrm{Zn}$, $\mathrm{Cr}, \mathrm{V}, \mathrm{Mo}$, and Se were in the limit value for sensitive soil according to the Romanian Law no. 756/1997. However, the following essential elements such as Ca 108,099 mg/kg d.w., $\mathrm{Mg} 3171 \mathrm{mg} / \mathrm{kg}$ d.w., Na $132 \mathrm{mg} / \mathrm{kg}$ d.w., and Fe 14,523 mg/kg d.w. were detected.

All the soil samples' pH values (Mettler Toledo SevenGo) measured before and during the experiments ranged from 6.21 to 6.64 for control and 5.34 to 5.83 for contaminated soil.

The quality of water used for plants watering during the test period corresponded to free chlorine potable water, and no toxic heavy metals were detected. As, Cd, Co, Cr, Ni, $\mathrm{Pb}, \mathrm{V}, \mathrm{Mo}$, Se, and $\mathrm{Sb}$ values were below the method quantification limits. Moreover, $\mathrm{Cu}$ $5.1 \mu \mathrm{g} / \mathrm{L}, \mathrm{Mn} 2.6 \mu \mathrm{g} / \mathrm{L}$, Fe $39.3 \mu \mathrm{g} / \mathrm{L}, \mathrm{Zn} 16.3 \mu \mathrm{g} / \mathrm{L}, \mathrm{Ca} 41.8 \mu \mathrm{g} / \mathrm{L}, \mathrm{Mg} 4.8 \mu \mathrm{g} / \mathrm{L}$, and Al $109 \mu \mathrm{g} / \mathrm{L}$ were found in the soaking water.

\subsection{Metals Concentration in Soil Samples}

Figures 1-4 present the results of $\mathrm{As}, \mathrm{Cd}, \mathrm{Ni}$, and $\mathrm{Pb}$ concentrations detected in the enriched soil from May to July. After one week of exposure, the contaminated soil samples from the experiments $\mathrm{AsCd}$ and $\mathrm{AsCdNiPb}$ showed significant metals content compared to the control $(p<0.05)$, which was mainly due to metal soil enrichment. However, metal concentrations (As, $\mathrm{Cd}, \mathrm{Ni}, \mathrm{Pb}$ ) were below the intervention threshold for sensitive use, so As and $\mathrm{Cd}$ content was above the alert threshold for both $\mathrm{AsCd}$ and $\mathrm{AsCdNiPb}$ experiments, respectively. In the case of the $\mathrm{AsCdNiPb}$ experiment, $\mathrm{Ni}$ and $\mathrm{Pb}$ concentrations slowly increased over the normal value. The metal concentration detected in the soil samples from May and July in case of the three experiments showed a correlation coefficient of $r=0.99$, pointing out that the metals accumulation in soil has the same tendency.

Slight differences $(p>0.05)$ were observed between the metals concentration results from the two depths samples $(0-6 \mathrm{~cm}$ and $6-12 \mathrm{~cm})$.

Generally, at the top soil layer, the metallic elements were found in high concentrations compared to the bottom soil layer for both experiments. Exceptions were observed in case of $\mathrm{Ni}$ and $\mathrm{Pb}$ with the same distribution between layers in the AsCd experiment similar to those detected in control sample (M). Ni and $\mathrm{Pb}$ were added in soil only in experiment 
AsCdNiPb (in mix with As and Cd). Similarly, these elements increase in the bottom soil layer at the final of test (July) in case of the AsCdNiPb experiment.

The metal concentration differences recorded between the two experiments in May can be explained by: (i) uneven homogenization of the soil with the metal solutions added through watering; (ii) the distribution of metals influenced by the substrate characteristics; and (iii) the plant absorption in a week of exposure.

The remanence of metals in soil at the end of the experiment was as follows: $100 \%$ of As, $98 \%$ of $\mathrm{Cd}, 88-95 \%$ of $\mathrm{Ni}$, and $92 \%$ of $\mathrm{Pb}$. The differences of metals amounts in case of $\mathrm{Cd}, \mathrm{Ni}$, and $\mathrm{Pb}$ were accumulated by mint plants.

Temporal analyses showed insignificant variations of soil metal concentrations, except for July, when an increase in the bottom soil layer of metals concentrations was observed. The variation was not significant $(p>0.05)$ as a result of metals mobility assisted by soaking.

Moreover, about $20 \%$ difference in As concentration between $\mathrm{AsCd}$ and $\mathrm{AsCdNiPb}$ experiments was noticed, although a similar concentration $(23.7 \mathrm{mg} / \mathrm{kg} \mathrm{d}$.w.) was added for both experiments. Significant differences in As content at the two depths $(p=0.005)$ in case of AsCd experiment were recorded.

Considering the homogeneity and chemical stability, no significant changes in the metal distribution in control samples between depths and according to the exposure time $(p>0.05)$ were observed.

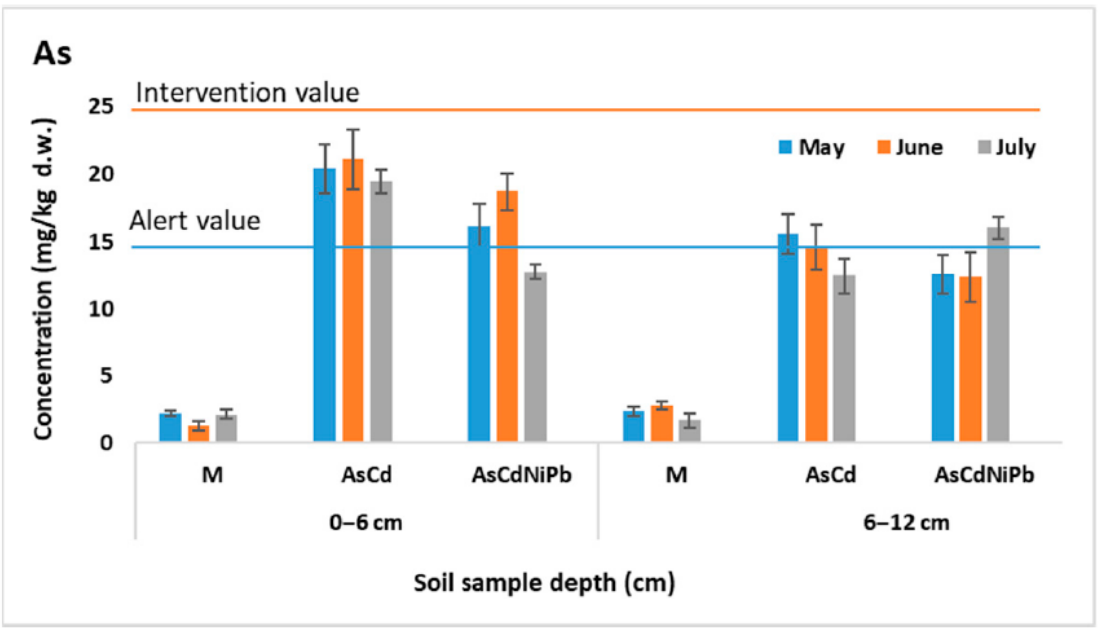

Figure 1. Variation of As concentration in soil (average $\pm \mathrm{SD}, n=6$ ).

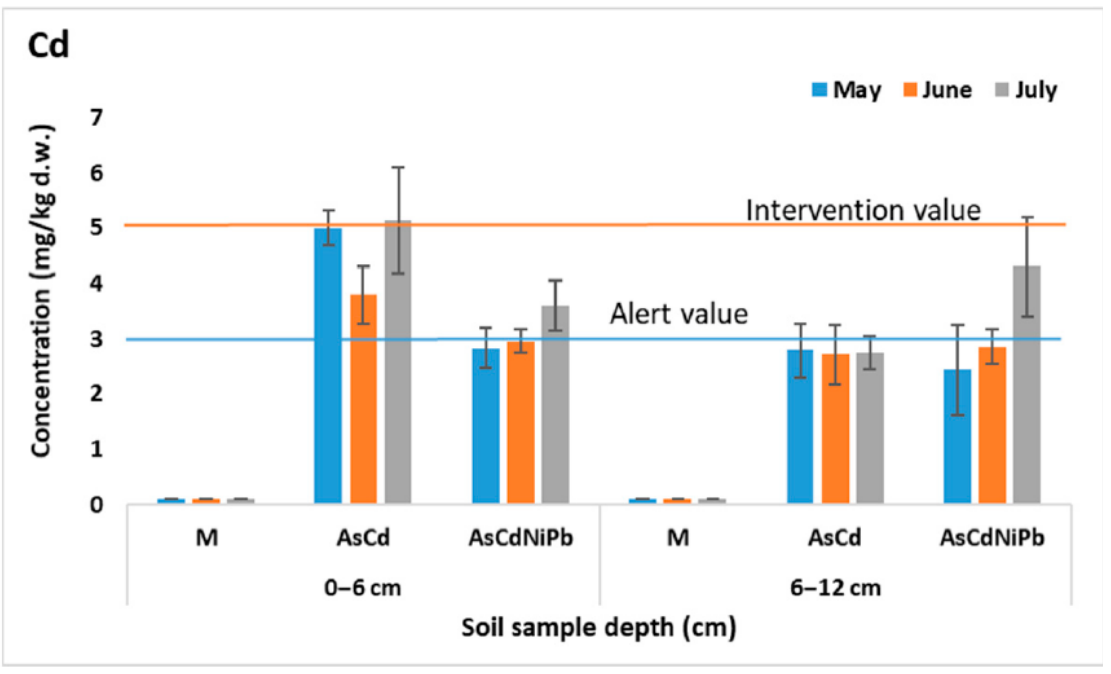

Figure 2. Variation of $\mathrm{Cd}$ concentration in soil (average $\pm \mathrm{SD}, n=6$ ). 


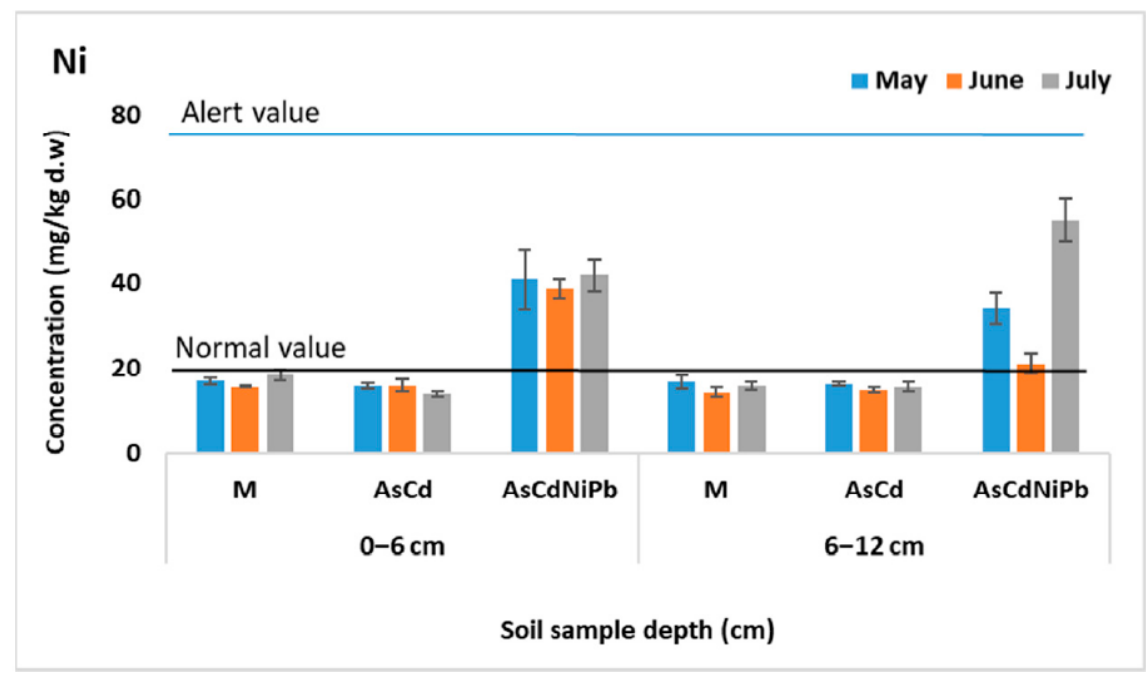

Figure 3. Variation of $\mathrm{Ni}$ concentration in soil (average $\pm \mathrm{SD}, n=6$ ).

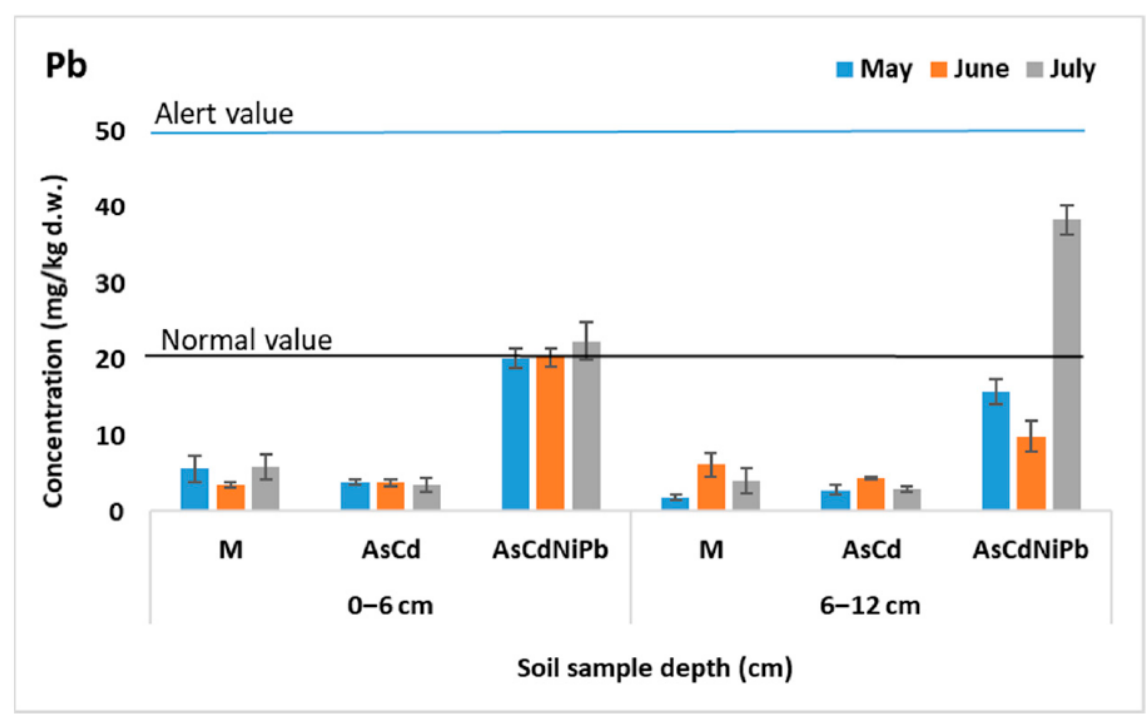

Figure 4. Variation of $\mathrm{Pb}$ concentration in soil (average $\pm \mathrm{SD}, n=6$ ).

\subsection{Metals Concentration in Mint Samples}

Control mint plants showed no metal concentration higher than other reported studies or WHO limits. Instead, differences in metal concentration were emphasized. Very significant $(p<0.01)$ differences of $\mathrm{Cd}$ and $\mathrm{Ni}$ content in the root-stem system and no significant changes $(p>0.05)$ in root-leaves and stem-leaves were recorded. In root-leaves systems, Ni showed significant changes due to the concentration registered in root $(p=0.01)$. In addition, no significant change $(p>0.05)$ was detected between plant organs in controls in case of $\mathrm{Pb}$ concentration (Table 3 ). 
Table 3. The $p$ values applied to plant organs in terms of metals $(\mathrm{Cd}, \mathrm{Ni}$, and $\mathrm{Pb})$ in the exposed period (May-July).

\begin{tabular}{ccccc}
\hline \multirow{2}{*}{ Plant Organ System } & Experiment & \multicolumn{3}{c}{$p$ Values } \\
\cline { 3 - 5 } & & $\mathbf{C d}$ & $\mathbf{N i}$ & $\mathbf{P b}$ \\
\hline \multirow{2}{*}{ Root-stem } & $\mathrm{M}$ & $* *(0.002)$ & $* *(0.008)$ & $\mathrm{ns}(0.135)$ \\
& $\mathrm{AsCd}$ & $* *(0.0001)$ & $*(0.014)$ & $*(0.043)$ \\
& $\mathrm{AsCdNiPb}$ & $*(0.022)$ & $* *(0.003)$ & $\mathrm{ns}(0.110)$ \\
Root-leaves & $\mathrm{M}$ & $\mathrm{ns}(0.062)$ & $*(0.018)$ & $\mathrm{ns}(0.256)$ \\
& $\mathrm{AsCd}$ & $* *(0.0001)$ & $\mathrm{ns}(0.255)$ & $*(0.036)$ \\
& $\mathrm{AsCdNiPb}$ & $*(0.010)$ & $* *(0.002)$ & $*(0.038)$ \\
Stem-leaves & $\mathrm{M}$ & $\mathrm{ns}(0.445)$ & $\mathrm{ns}(0.276)$ & $\mathrm{ns}(0.280)$ \\
& $\mathrm{AsCd}$ & $\mathrm{ns}(0.303)$ & $\mathrm{ns}(0.159)$ & $\mathrm{ns}(0.186)$ \\
& $\mathrm{AsCdNiPb}$ & $\mathrm{ns}(0.169)$ & $\mathrm{ns}(0.306)$ & $*(0.030)$ \\
\hline
\end{tabular}

Note: ns (insignificant) $p>0.05,{ }^{*}$ significant $p<0.05,{ }^{* *}$ very significant $p<0.01$.

The analysis of exposed mint plants showed the presence of toxic metals except for As. The value of As concentration detected in Mentha piperita was below the quantification limit of the method in root, stem, and leaves for both experiments ( $\mathrm{AsCd}$ and $\mathrm{AsCdNiPb}$ ), although the As content $(23.7 \mathrm{mg} / \mathrm{kg}$ d.w.) which was added in soil reached the threshold intervention value $(25 \mathrm{mg} / \mathrm{kg}$ d.w.).

Normal values $(<1 \mathrm{mg} / \mathrm{kg}$ d.w.) of $\mathrm{Cd}$ concentrations were found in the aerial parts of the mint plants during the entire experiment period. On the contrary, $\mathrm{Cd}$ concentration in root was higher than $1 \mathrm{mg} / \mathrm{kg}$ d.w (AsCd test: $1.07 \mathrm{mg} / \mathrm{kg}$ d.w. in June and $1.16 \mathrm{mg} / \mathrm{kg}$ d.w in July; AsCdNiPb test: 1.09 mg/ mg/kg d.w. in June and $1.56 \mathrm{mg} / \mathrm{kg}$ d.w in July) (Figure 5).

$\mathrm{Cd}$ had a higher concentration in stem (in June) and leaves (in July) for AsCdNiPb compared to AsCd in the experiment and exceeded the WHO maximum permissible value (0.03 mg/kg d.w.).

Slight modifications were observed in case of Ni (Figure 6) and Pb (Figure 7) concentrations in the AsCd experiment compared to the control experiment (M). Additionally, $\mathrm{Ni}$ and $\mathrm{Pb}$ were added to the soil only in the $\mathrm{AsCdNiPb}$ experiment. Both metals $\mathrm{Ni}$ (19.52 $\mathrm{mg} / \mathrm{kg} \mathrm{d.w})$ and $\mathrm{Pb}(11.88 \mathrm{mg} / \mathrm{kg} \mathrm{d.w})$, respectively, had maximum values in the mint root in July, exceeding the limit for the normal plant development $(5 \mathrm{mg} / \mathrm{kg}$ d.w. $)$. This observation was correlated with the same trend of $\mathrm{Ni}$ and $\mathrm{Pb}$ values detected in soil in July, where the highest concentrations of this metals were observed. Therefore, the results could be influenced by plant capacity to absorb and retain these metals in different developmental stages and the metals' bioavailability.

$\mathrm{Ni}$ showed a similar behavior as $\mathrm{Cd}$ in the root-stem system, accumulating more in roots than in the stems and leaves $(p<0.01)$. Comparing the root-leaves concentrations, $\mathrm{Ni}$ showed $p$ values $>0.05$ in the AsCd experiment and $p<0.01$ in the AsCdNiPb experiment, both in root, as we expected due to Ni addition (Table 3).

No significant changes were observed for $\mathrm{Cd}$ and $\mathrm{Ni}$ between stem and leaves.

$\mathrm{Pb}$ had a similar behavior as $\mathrm{Cd}$ and $\mathrm{Ni}$, accumulating mostly in the root of the plant. $\mathrm{Pb}$ concentrations $(0.2$ to $1.35 \mathrm{mg} / \mathrm{kg})$ in AsCd were similar with the ones detected in the control experiment (M) (0.4 to $2.13 \mathrm{mg} / \mathrm{kg})$. The highest concentration was detected in the root samples in July for the AsCdNiPb experiment (11.88 mg $/ \mathrm{kg}$ d.w.). The $\mathrm{Pb}$ concentrations were significantly different $(p=0.03$ to 0.04$)$ in roots compared to aerial organs (Table 3).

Comparing the same plant organ in the experiments, we observed very significant $(p<0.01)$ and significant $(p<0.05)$ differences of $\mathrm{Cd}, \mathrm{Ni}$, and $\mathrm{Pb}$ concentrations between control experiments and contaminated experiments (Table 4) at the root and stem level. There were no changes in $\mathrm{Cd}$ and $\mathrm{Ni}$ concentrations comparing the data obtained for $\mathrm{AsCd}$ and $\mathrm{AsCdNiPb}$. The differences in $\mathrm{Ni}$ and $\mathrm{Pb}$ were due to the addition of this element 
in $\mathrm{AsCdNiPb}$. No significant changes were observed for the leaves comparing all the experiment data.

The experiments showed that metals accumulation in mint was as follows: root $>$ stem $>$ leaves.

Table 4. The $p$ values for the controls and polluted experiments using the data obtained for the same plant organ in the exposed period (May-July).

\begin{tabular}{|c|c|c|c|}
\hline \multirow{2}{*}{ Plant Organ/Experiment } & \multicolumn{3}{|c|}{$p$ Values } \\
\hline & $\mathrm{Cd}$ & $\mathrm{Ni}$ & $\mathbf{P b}$ \\
\hline \multicolumn{4}{|l|}{ Root } \\
\hline $\mathrm{M} / \mathrm{AsCd}$ & $* *(0.001)$ & ns $(0.327)$ & ns (0.404) \\
\hline $\mathrm{M} / \mathrm{AsCdNiPb}$ & $* *(0.009)$ & $* *(0.0005)$ & $*(0.048)$ \\
\hline $\mathrm{AsCd} / \mathrm{AsCdNiPb}$ & ns $(0.234)$ & $* *(0.005)$ & ns $(0.074)$ \\
\hline \multicolumn{4}{|l|}{ Stem } \\
\hline $\mathrm{M} / \mathrm{AsCd}$ & ns $(0.191)$ & ns $(0.381)$ & ns (0.179) \\
\hline $\mathrm{M} / \mathrm{AsCdNiPb}$ & $*(0.030)$ & $*(0.012)$ & $*(0.040)$ \\
\hline $\mathrm{AsCd} / \mathrm{AsCdNiPb}$ & * (0.049) & $* *(0.009)$ & $*(0.040)$ \\
\hline \multicolumn{4}{|l|}{ Leaves } \\
\hline $\mathrm{M} / \mathrm{AsCd}$ & ns (0.491) & ns (0.197) & ns (0.103) \\
\hline $\mathrm{M} / \mathrm{AsCdNiPb}$ & ns $(0.247)$ & ns $(0.089)$ & ns (0.188) \\
\hline $\mathrm{AsCd} / \mathrm{AsCdNiPb}$ & ns $(0.220)$ & ns $(0.171)$ & ns (0.095) \\
\hline
\end{tabular}

Note: ns (insignificant) $p>0.05,{ }^{*}$ significant $p<0.05,{ }^{* *}$ very significant $p<0.01$.

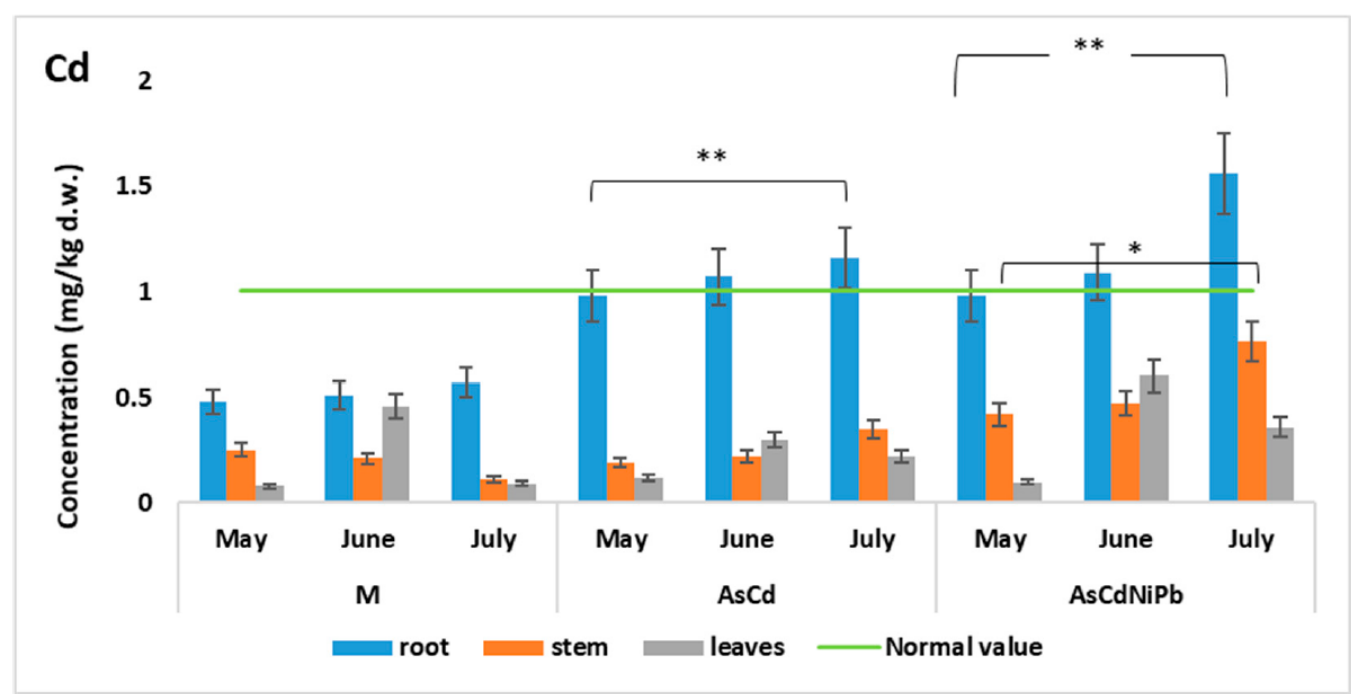

Figure 5. Variation of Cd concentration in Mentha piperita. The gray lines on the top indicate significant differences: ${ }^{*}$ in root $(p<0.01)$ and ${ }^{*}$ in stem $(p<0.05)$, during the exposed period (from May to July) compared to control (M). 


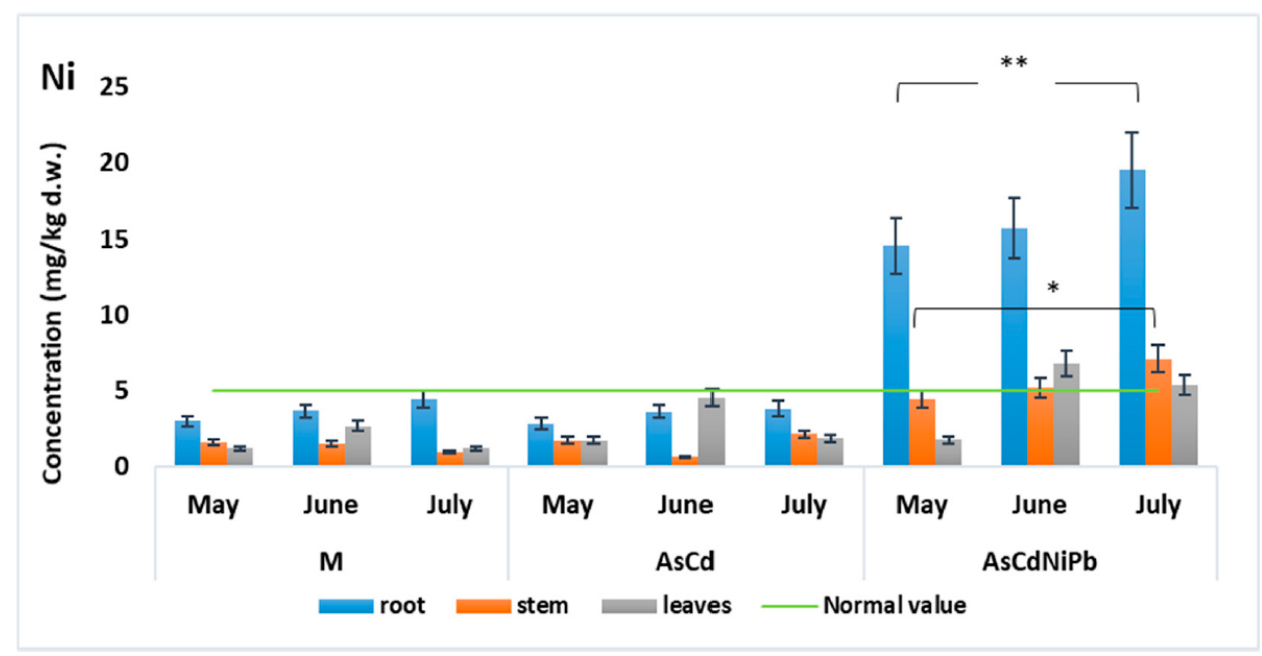

Figure 6. Variation of Ni concentration in Mentha piperita. The gray lines on the top indicate significant differences: ${ }^{* *}$ in root $(p<0.01)$ and ${ }^{*}$ in stem $(p<0.05)$, during the exposed period (from May to July) compared to control (M).

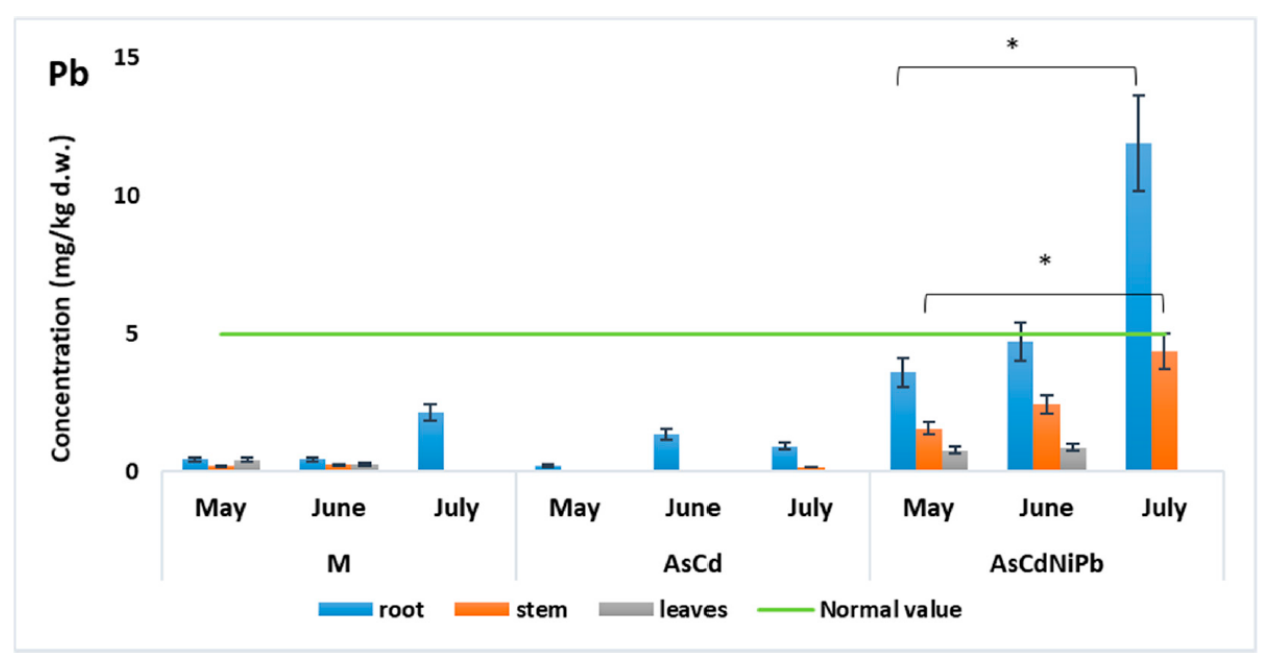

Figure 7. Variation of $\mathrm{Pb}$ concentration in Mentha piperita. The gray lines on the top indicate significant differences: * in root and stem $(p<0.05)$, during the exposed period (from May to July) compared to control (M).

\subsection{Biometrical Measurements and Chlorophyll Detection}

Figure $8 \mathrm{~A}-\mathrm{C}$ shows the biometrical measurements of mint leaves. The data collected after one month showed significant differences in length $(p=0.018)$-Figure 8A and weight $(p=0.009)$-Figure $8 \mathrm{C}$ of the leaves foliar surfaces compared to the control in the AsCd experiment. The plants exposure to the $\mathrm{AsCdNiPb}$ combination revealed a significant change in leaf surfaces $(p=0.021)$-Figure $8 \mathrm{~B}$ correlated with the decrease of weight compared to the control. The stem elongation in control was $30 \pm 4 \mathrm{~cm}$, and in tests, it was $27 \pm 5 \mathrm{~cm}$.

At the end of the test in June, the mint plants exposed to metals showed phytotoxic effects translated by leaf fall and chlorosis. The stems showed an elongation of $46 \pm 7 \mathrm{~cm}$ and rare leaves compared to the control plants with a growth of $54 \pm 5 \mathrm{~cm}$ and an abundance of leaves. It was observed a reduction in the roots size for $\mathrm{AsCd}$ and $\mathrm{AsCdNiPb}$ tests compared to the control.

The $\mathrm{AsCdNiPb}$ experiment revealed an increase in chlorophyll content (Figure 9) compared to AsCd experiment and control test. Moreover, chlorophyll $b$ content was 
higher compared to chlorophyll $a$. Our results showed that total chlorophyll increased proportionally with chemical elements supplementation.

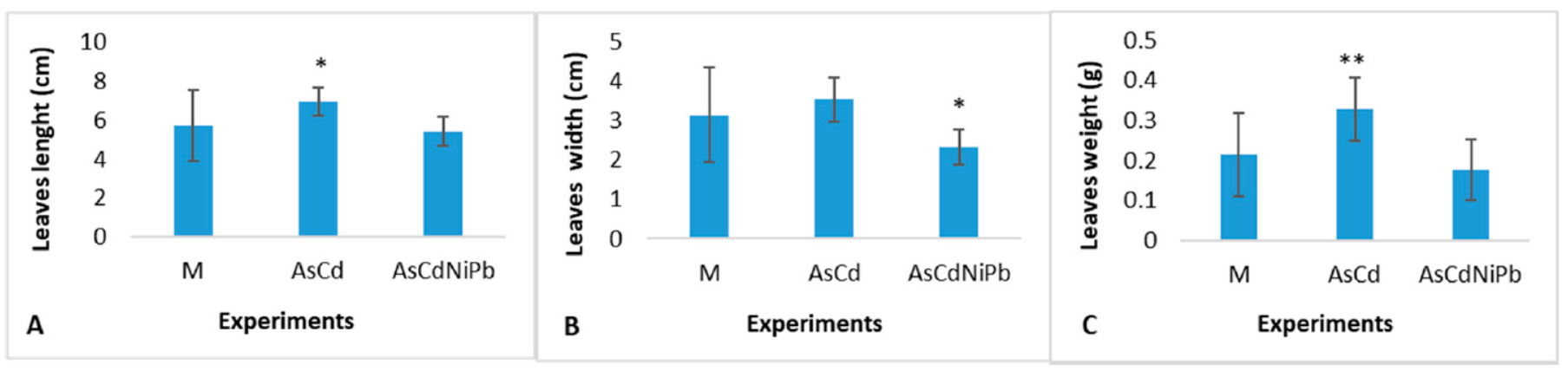

Figure 8. Biometrical data of Mentha piperita leaves (after 1 month of exposure), expressed as average $\pm \operatorname{SD}(n=12)$, where: (A) —Leaves length; (B)—Leaves width; (C) —Leaves weight; and * significant differences $(p<0.05)$, ** very significant differences $(p<0.01)$ compared to control $(\mathrm{M})$

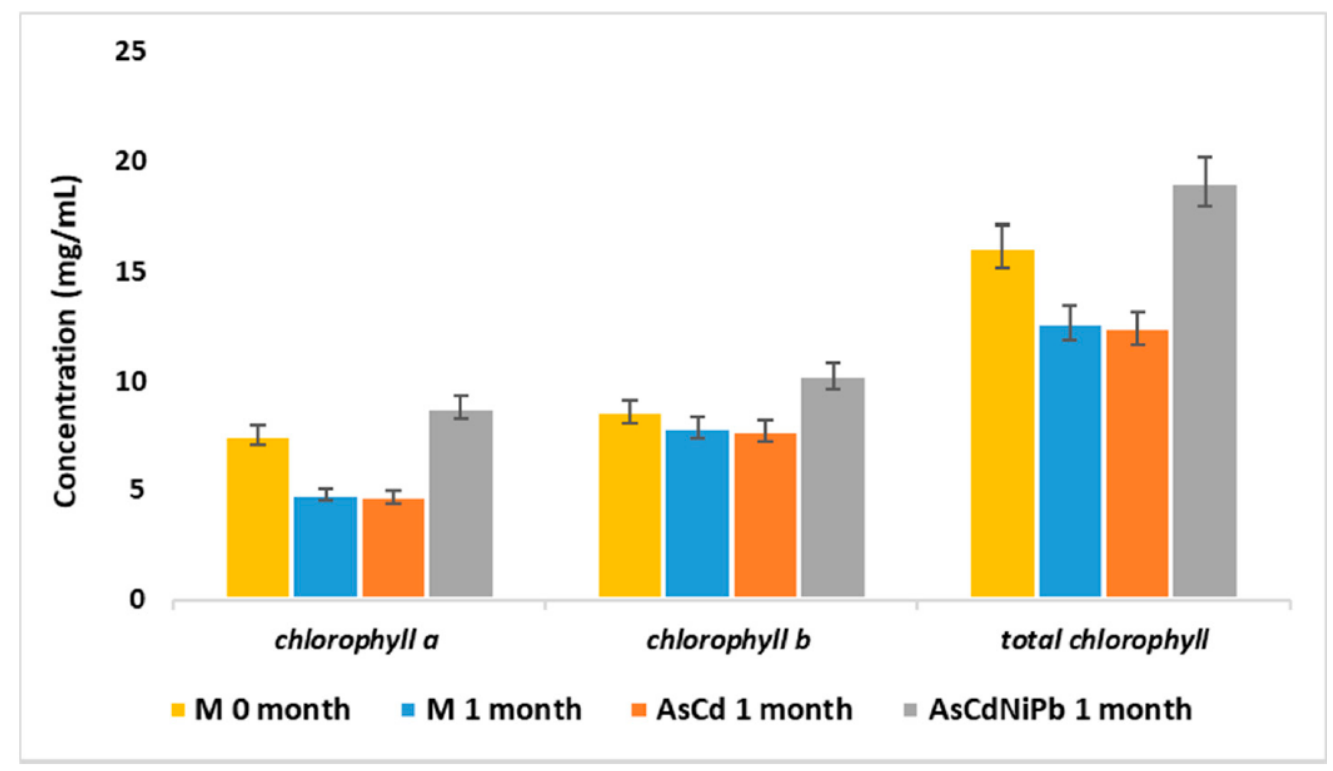

Figure 9. Chlorophyll pigments concentration in Mentha piperita leaves, expressed as average \pm SD $(n=4)$.

\subsection{Transfer Coefficient (TC) and Translocation Factor (TF)}

The TC values were calculated as the ratio between the average of metal concentration in the roots divided by the average of metal concentration detected in the soil. The TF values represent the ratio between the average of metal concentration in the aerial part of the plant divided by the average metal concentration detected in the roots.

TC values remained constant for all elements with a slight increase in case of polluted samples (Figure 10). The TC values calculated for $\mathrm{Cd}, \mathrm{Ni}$, and $\mathrm{Pb}$ were below 1 for both experiments ( $\mathrm{AsCd}$ and $\mathrm{AsCdNiPb}$ ). For $\mathrm{Cd}$, the transfer coefficient values in $\mathrm{AsCd}$ and AsCdNiPb experiments ranged between 0.2 and 0.48 ; for $\mathrm{Pb}$, the $\mathrm{TC}$ values were between 0.10 and 0.43 , and for $\mathrm{Ni}$, the TC values varied between 0.17 and 0.53 .

The studied metals were not efficiently translocated in aerial parts of plants. The TF values were below 1, indicating a non-efficient translocation of metals between organs (Figures 11 and 12). Ni translocation from root to stem increased comparing with $\mathrm{Pb}$ in the AsCdNiPb experiment. This indicates the Ni utilization in plant nutrition. $\mathrm{Cd}$ translocation in stem was superior in the $\mathrm{AsCdNiPb}$ experiment as in case of the AsCd experiment, but it was not significant. 
The TF values calculated for root/leaves revealed $\mathrm{Ni}$ increased values for all experiments, the maximum TC value being 1.28 in the AsCd experiment. This TC value indicated the transfer of $\mathrm{Ni}$ from root to leaves, the average concentrations of $7 \mathrm{mg} / \mathrm{kg}$ were situated under a phytotoxic value of $30 \mathrm{mg} / \mathrm{kg}$ in plants. Moreover, differences between the pollutants combinations and control $(\mathrm{M})$ were observed. Ni presented lower TF values in the $\mathrm{AsCdNiPb}$ experiment (in control range) as to the $\mathrm{AsCd}$ experiment. The TF value of $\mathrm{Cd}$ increased about $40 \%$ in June in the $\mathrm{AsCdNiPb}$ experiment in comparison to the same period in the AsCd experiment, but in July, the TF values decreased at 0.19 in both combinations, being in the control range.

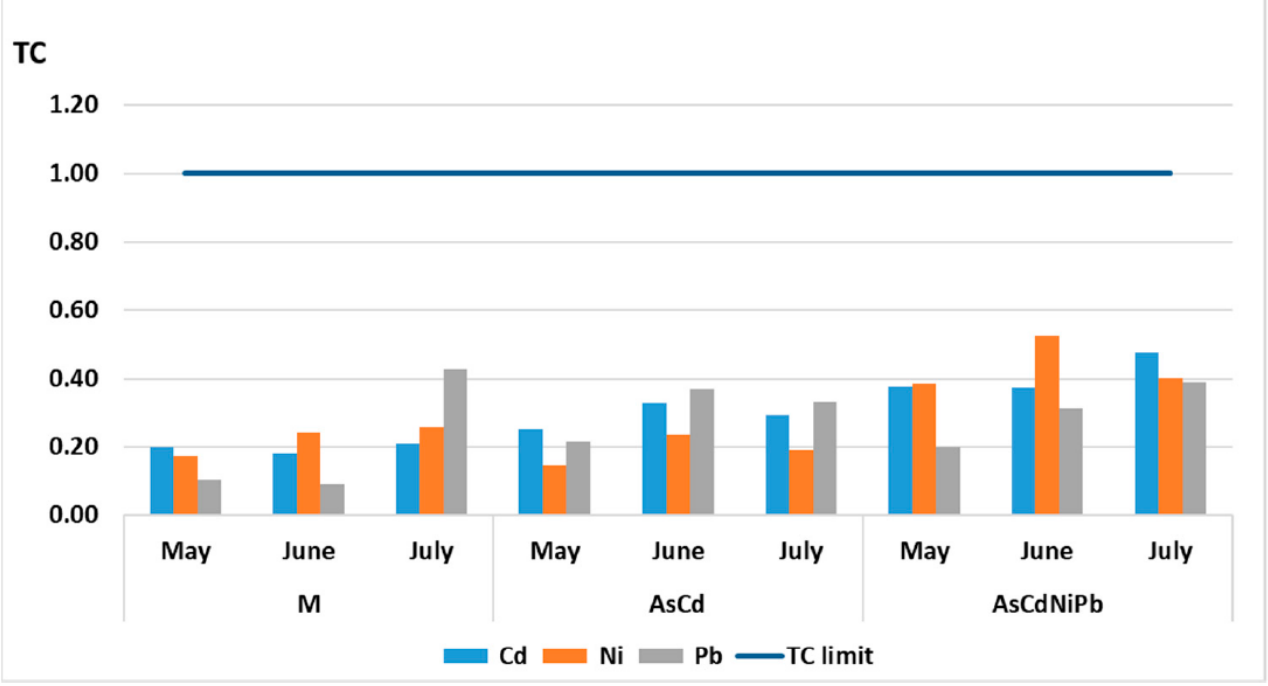

Figure 10. Transfer coefficient (TC) of metals from soil to Mentha piperita root.

\section{TF root/stem}

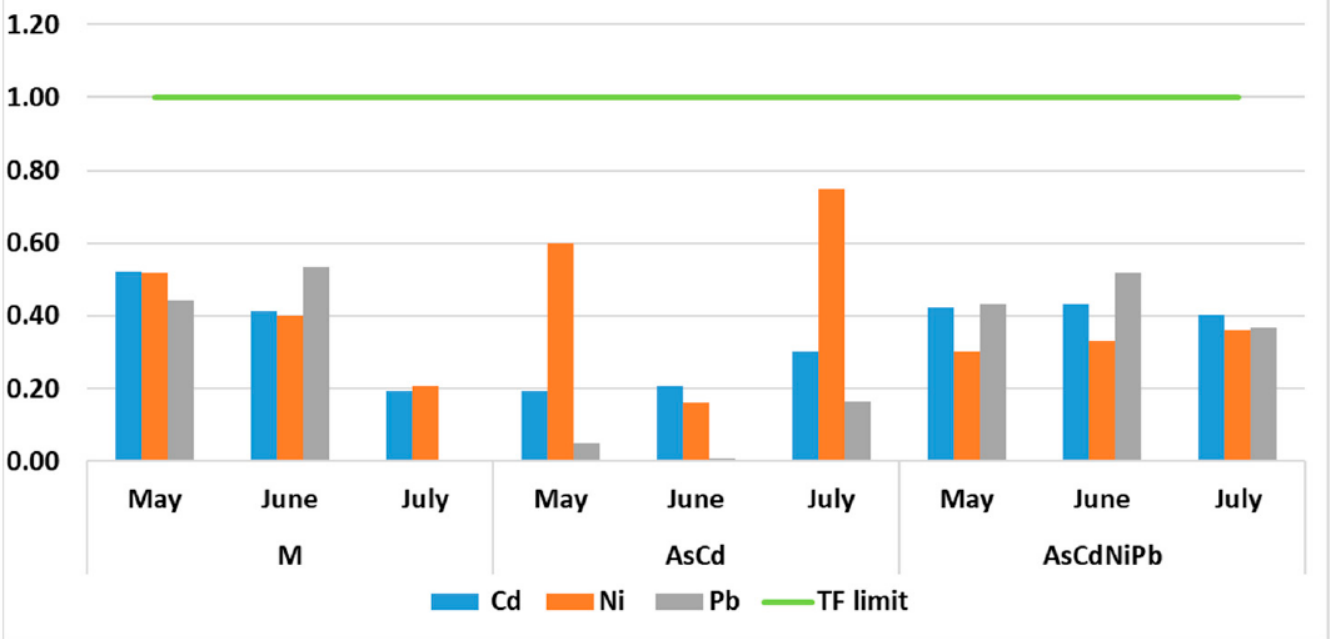

Figure 11. Translocation factor (TF) of metals from root to stem in Mentha piperita. 


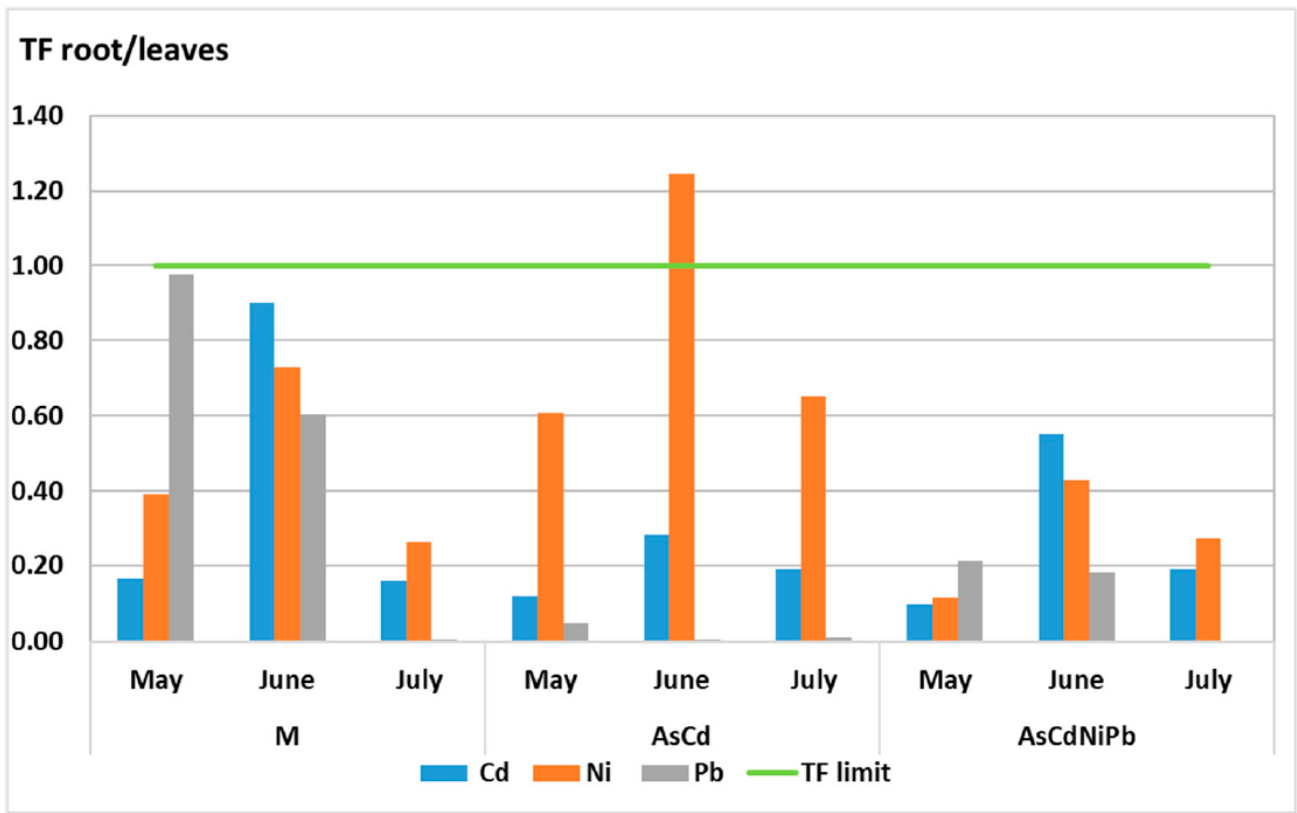

Figure 12. Translocation factor (TF) of metals from root to leaves in Mentha piperita.

\section{Discussion}

\subsection{Metals Concentration in Mint Samples}

Heavy metals uptake by plants is achieved through diffusion or active uptake at the root level by ion exchange between clay and the root surface, which is a process facilitated by different biotic and abiotic factors.

Our results of metals concentration in plant samples were compared with the literature limits. The concentrations of studied metals specified in the literature in plants were As 0.01 to $0.06 \mathrm{mg} / \mathrm{kg}$ [8], Cd less than 0.1 to $1 \mathrm{mg} / \mathrm{kg}$, Ni from 0.1 to $5 \mathrm{mg} / \mathrm{kg}$ [52], and $\mathrm{Pb}$ from 1 to $5 \mathrm{mg} / \mathrm{kg}$ [43]. The concentrations that could induce phytotoxic effects in plants are As $2 \mathrm{mg} / \mathrm{kg}$, Cd $10 \mathrm{mg} / \mathrm{kg}$, Ni $30 \mathrm{mg} / \mathrm{kg}$ [53], and $\mathrm{Pb} 20 \mathrm{mg} / \mathrm{kg}$ [9]. Moreover, WHO established the maximum permissible limits in food plants as follows: As $1 \mathrm{mg} / \mathrm{kg}, \mathrm{Cd}$ $0.03 \mathrm{mg} / \mathrm{kg}$, and $\mathrm{Pb} 10 \mathrm{mg} / \mathrm{kg}$ [16].

The plant samples showed different metal concentrations of $\mathrm{Cd}, \mathrm{Ni}$, and $\mathrm{Pb}$, except for As. The values of As in Mentha piperita grown in laboratory conditions were under detection limits in all plant samples. Some studies reported that the As bioavailable concentration from soil is lower than the total content because As tend to form stable compounds that are less bioavailable and depend on the soil-water-plant system [54]. As is strongly absorbed by $\mathrm{Fe}, \mathrm{Mn}$, and $\mathrm{Al}$ hydroxides and clays [55]. Furthermore, the use of some inorganic (ferrous sulfate, lamination slags, iron-bearing additives, goethite, metallurgical byproducts, red mud, all based especially on Fe and Mg oxides) or organic biochar obtained from different vegetal, industrial, or municipal wastes) could reduce the mobility of arsenic in plants but induce the decreases of biomass development. Due to low availability in soil, As has been reported in plants in very small concentration of even less $10 \mu \mathrm{g} / \mathrm{kg}$ [56].

The used garden soil and their characteristics regarding the low acidity $(\mathrm{pH}=6.7)$, clay, and the presence of other nutritive components $\left(\mathrm{P}_{\text {total }}=4173 \mathrm{mg} / \mathrm{kg}, \mathrm{N}_{\text {total }}=12,055 \mathrm{mg} / \mathrm{kg}\right.$, $\mathrm{K}=1872 \mathrm{mg} / \mathrm{kg})$ and essential metals $(\mathrm{Cu}, \mathrm{Zn}, \mathrm{Mg}, \mathrm{Ca}, \mathrm{Fe}, \mathrm{Co}$, and $\mathrm{Ni}$ ) could explain the As low availability to plant roots. Some studies report that soil fertilization with phosphorus can induce the accumulation of As in plants [19], but other studies disapprove this observation. The high concentration of phosphorus favors the transfer of phosphates at the roots rather than arsenic compounds due to specific phosphate transporters specifically built for oxyanion, contributing to the reduction of As accumulation in plants [57]. 
In addition, the used substrate contained an important concentration of Fe $(14,523 \mathrm{mg} / \mathrm{kg}$ d.w.) and $\mathrm{Mn}(373 \mathrm{mg} / \mathrm{kg} \mathrm{d.w.}$ ) that could prevent As transfer in plant.

$\mathrm{Cd}$ concentration showed changes in the systems root-stem and root-leaves in both experiments. $\mathrm{Cd}$ accumulation decreases proportionally with $\mathrm{Ni}$ and $\mathrm{Pb}$ supplementation in the $\mathrm{AsCdNiPb}$ experiment. Similar results were obtained in other studies on Mentha piperita where the $\mathrm{Cd}$ concentration decreased in plant organs when this element is combined with $\mathrm{Pb}$ or $\mathrm{Cu}$, thus indicating a competition between these two metals at the root level [38].

Insignificant changes in $\mathrm{Ni}$ and $\mathrm{Pb}$ concentrations detected in plants were observed.

It is known that $\mathrm{Ni}$ is an essential element involved in the plant growth and development, photosynthesis processes, as well as in the plant nutrition. Therefore, the absorption of Ni by Mentha piperita was not influenced by the addition of As and Cd. Plants accumulated Ni mostly in the root, but the concentration detected in the aerial parts (stem and leaves) in the AsCdNiPb experiment exceeded the normal value in plants $(5 \mathrm{mg} / \mathrm{kg}$ ) (Figure 6). The WHO established no maximum permissible limit for Ni in food plants, which was probably due to the benefit of this element for plants development and due to the high phytotoxic limit $(30 \mathrm{mg} / \mathrm{kg}$ ).

$\mathrm{Pb}$ concentration did not exceed the maximum value allowed by the WHO $(10 \mathrm{mg} / \mathrm{kg})$ and normal value $(5 \mathrm{mg} / \mathrm{kg})$ in any parts of the plant that are used for medicinal purposes such as stem and leaves (Figure 7). Similar studies showed that $\mathrm{Pb}$ tends to accumulate mostly in plant roots, and only a small amount is transported to the stem and leaves $[38,58]$.

As a general observation, the studied metals were retained mostly in the root rather than the aerial parts. This fact can be explained by the ability of metals as cations $\left(\mathrm{Cd}^{2+}\right.$, $\left.\mathrm{Ni}^{2+}, \mathrm{Pb}^{2+}\right)$ to attach to negative charge sites of root cell walls, thus restricting the transfer from the root to the aerial parts [59].

The experiments $(\mathrm{M}, \mathrm{AsCd}$, and $\mathrm{AsCdNiPb})$ pointed out that the rank of metals accumulation in mint samples was as follows: root $>$ stem $>$ leaves. One exception was for $\mathrm{Ni}$ and $\mathrm{Cd}$ in June, where for all the experiments, the metal accumulation order was root $>$ leaves $>$ stem. The same results were obtained in other studies for Allium sativum L. plant [60] and Mentha spicata [59].

\subsection{Biometrical Measurements and Chlorophyll Detection}

Growth inhibition is one of the symptoms of metal toxicity. The measurements performed for the mint leaves collected after one month of exposure showed positive changes in biomass and foliar size compared to the control. We assume that the additions of metals could stimulate the plant growth in case of the AsCd experiment and did not have visible effects in case of the $\mathrm{AsCdNiPb}$ experiment after one month of exposure. The same observations on plant growth were made in previous studies on Ocimum basilicum L. plants grown in a mining-contaminated soil. The presence of metals in different concentrations for a limited exposure time could influence plant development, these being involved in plant metabolic processes. Moreover, the plants could adopt particular survival strategies including a metal detoxification process or could favor the absorption of some metals to the detriment of others, the toxic metals being in competitions with essential metals or other nutrients [27].

The plants' growth in the AsCdNiPb system showed an increased chlorophyll content after one month of exposure compared to the AsCd experiment, but at the end of the tests, the plants' state changed. After three months of exposure, phytotoxic effects occurred, namely chlorosis and leaves loss.

Chlorophyll content as an indicator of the photosynthetic system as well as plant robustness can offer responses on the soil quality [23]. Houri et al. stated that the overload of heavy metals could lead to photosynthetic system damage, followed by chlorophyll pigments increase as an adaptation method [61]. After one month of exposure, the enrichment with metals influenced both the photosynthetic process measured by the total chlorophyll concentration (Figure 9) and plant biomass quantified as leaves surface and weight (Figure 8). 
Similar phytotoxic effects were reported when Cd prolonged exposure occurs $[62,63]$. In medicinal plants, metals can compete with the uptake of nutrients $\mathrm{N}, \mathrm{P}, \mathrm{K}$ by the plant, thus leading to macronutrient deficiency followed by chlorosis, growth involution, and leaf necrosis [64].

In addition, $\mathrm{Pb}(5-50 \mathrm{mg} / \mathrm{L})$ can cause visible symptoms of toxicity causing damage to cell structures, reactive oxygen species (ROS) accumulation, and alteration of essential oils composition [65]. On the contrary, some studies on Mentha spicata L. showed no significant changes in oil plant constituents as a specific response to metal contamination [40]. By contrast, it was stated that Mentha piperita when exposed to $\mathrm{Pb}$ and $\mathrm{Cr}$ could improve its yield of essential oil and biomass [66].

\subsection{Transfer Coefficient (TC) and Translocation Factor (TF)}

The metals transfer inside of roots generally occurs through passive diffusion at the cell membrane level or throughout active transfer based on the gradient of concentrations. The active transfer is a natural plant-specific process used for the absorption of essential elements. In addition, it represents the pathway of other toxic available elements. To tolerate the non-essential elements, the plants use different strategies such as morphological, physiological, biochemical, and genetic processes [15].

The metal transfer from soil in mint plants was studied. The data showed that TC values remained constant for all metals being below 1 for both experiments (AsCd and $\mathrm{AsCdNiPb).} \mathrm{Mentha} \mathrm{piperita} \mathrm{immobilized} \mathrm{the} \mathrm{metals} \mathrm{in} \mathrm{root,} \mathrm{reducing} \mathrm{their} \mathrm{toxicity,} \mathrm{thus}$ developing a tolerant mechanism. A similar result was obtained for Cd (TF 0.61) in mint subjected to a combination of $\mathrm{Cd}, \mathrm{Ni}, \mathrm{Cr}, \mathrm{Pb}$, and $\mathrm{Co}$. No correlation between TF values of $\mathrm{Pb}$ (TF 1.08) and $\mathrm{Ni}$ (TF 1.16) was identified, which was probably due to the difference between the substrate characteristics [59].

Since the experiments were performed in high organic matter substrate, it was most likely that $\mathrm{Cd}, \mathrm{Pb}$, and As were not well-available for plant roots due to their ability to complex with organic matter and remain soil attached. Some studies reported that Mentha arvenis can accumulate $\mathrm{Cd}$ and $\mathrm{Pb}$ in roots and revealed an antagonistic behavior on the growth and physiological activities in the plant as a result of containing soil organic carbon [23].

The data showed a non-efficient translocation of metals between organs $(\mathrm{TF}<1)$. Mentha piperita was classified as an excluder plant for all tested metals $(\mathrm{Cd}, \mathrm{Ni}, \mathrm{Pb})(\mathrm{TC}<1)$ according to the principles of classification of medicinal plants as hyper-accumulators or excluders [41]. Prasad et al. showed that Mentha arvenis, Mentha piperita, and Mentha citrate are not hyper-accumulators for $\mathrm{Cr}$ and $\mathrm{Pb}$ [67]. Our results confirmed that Mentha piperita acts as a metal phytostabilizer [67-69].

\section{Conclusions}

The present study showed the behavior of one important medicinal plant (Mentha piperita) in the presence of several metals $(\mathrm{Cd}, \mathrm{Ni}, \mathrm{Pb}$, and $\mathrm{As})$ and their capacity to transfer metals to the aerial parts. The laboratory experiments focused on the behavior of mint plants exposed to metals combination, such as $\mathrm{AsCd}$ and $\mathrm{AsCdNiPb}$. After three months of exposure, the metals were found in the plants organs as follows: $\mathrm{Cd}>\mathrm{Ni}>\mathrm{Pb}>\mathrm{As}$. In addition, the order of metal accumulation in plant organs was root $>$ stem $>$ leaves.

The plants' short exposure to metals showed a positive impact on the growth and the leaves' biometrical parameters. Moreover, as a result of metals supplementation, total chlorophyll concentration increased in the first month of tests as an adaptation mode, which was followed by phytotoxic effects in the final test due to the long time exposure.

The transfer coefficients of metals $(\mathrm{Cd}, \mathrm{Ni}, \mathrm{Pb})$ from the soil to the plant root were below 1 for both $\mathrm{AsCd}$ and $\mathrm{AsCdNiPb}$ experiments, respectively. TC values for $\mathrm{Cd}$ ranged between 0.2 and 0.48 , for $\mathrm{Pb} 0.10 \div 0.43$, and for $\mathrm{Ni} 0.17 \div 0.53$. Mentha piperita immobilized the metals (case of $\mathrm{Cd}, \mathrm{Ni}, \mathrm{Pb}$ ) in roots, reducing their toxicity, developing a tolerant mechanism, or excluding the metal absorption by root (in case of $\mathrm{Pb}, \mathrm{As}$ ). 
The studied metals were not efficiently translocated in the aerial parts of plants. The translocation factors were below 1 , indicating a weak translocation of metals between vegetative organs. $\mathrm{Cd}$ and $\mathrm{Pb}$ were accumulated mainly in the root. Furthermore, it was observed that $\mathrm{Ni}$ was the only element of the four studied metals in which the transfer occurred from the root to the leaves based on their physiological implication. Our results confirmed that Mentha piperita acts as a metal phytostabilizer at the root level and is a metaltolerant plant if it uses a substrate with the described characteristics and the exposure period is no longer than one month. The long time exposure of mint plants to metals induces visible phytotoxic effects as a result of root development reduction.

Care should be given to the migration of metallic elements in parts of the plant used in medicinally human consumption. After the second month of exposure, $\mathrm{Cd}$ and $\mathrm{Ni}$ were detected in stem above the WHO limit. Medicinal plants grown in soils polluted with metals can raise quality problems of medicinal products, which requires rigorous control before use.

Author Contributions: Conceptualization, C.D. and G.-G.V.; methodology, C.D. and G.-G.V.; validation, C.D., G.-G.V. and A.G.T.; laboratory analysis, A.G.T., E.A.S., R.L.P. and C.S.; resources, L.F.P.; data curation, interpretation and statistical analyze, S.G.; writing-original draft preparation C.D.; writing - review and editing, S.G., G.-G.V. and C.S.; visualization, G.-G.V. and S.G.; project administration, G.-G.V.; funding acquisition, L.F.P. All authors have read and agreed to the published version of the manuscript.

Funding: This research was funded by The Romanian National Research Program "Nucleu" through contract no 20N/2019, Project code PN 19040101 and Project code PN 19040201.

Institutional Review Board Statement: Not applicable.

Informed Consent Statement: Not applicable.

Data Availability Statement: The data presented in this study are available on request from the corresponding author. The data are not publicly available due to ongoing research in this field carried out within the above mentioned projects.

Acknowledgments: The authors acknowledge the financial support offered by The Romanian National Research Program "Nucleu" through contracts no 20N/2019, Project code PN 19040101 and Project code PN 190402 01. In addition, the authors thanks for critical review to biol. Mihai Nita-Lazar from National Research and Development Institute for Industrial Ecology ECOIND Bucharest, Control Pollution Department.

Conflicts of Interest: The authors declare no conflict of interest.

\section{References}

1. Ghiyasi, S.; Karbassi, A.; Moattar, F.; Modabberi, S.; Sadough, M.B. Origin and concentrations of heavy metals in agricultural land around aluminum industrial complex. J. Food Agric. Environ. 2010, 8, 1237-1240.

2. Sarma, H.; Deka, S.; Deka, H.; Saikia, R.R. Accumulation of heavy metals in selected medicinal plants. Rev. Environ. Contam. Toxicol. 2011, 214, 63-86. [PubMed]

3. Matache, M.; Ropota, M.; Patroescu, C. The determination of heavy metals from wastewater of treatment plant Brasov by spectrometric techniques in plasma. Rev. Chim. 2003, 54, 217-220.

4. Gheorghe, S.; Stoica, C.; Vasile, G.G.; Nita-Lazar, M.; Stanescu, E.; Lucaciu, I.E. Metals Toxic Effects in Aquatic Ecosystems: Modulators of Water Quality. In Water Quality; InTech: London, UK, 2017.

5. Stoica, C.; Vasile, G.G.; Banciu, A.; Niculescu, D.; Lucaciu, I.; Lazar, M.N. Influence of anthropogenic pressures on groundwater quality from a rural area. Rev. Chim. 2017, 68, 1744-1748. [CrossRef]

6. Kim, L.; Vasile, G.G.; Stanescu, B.; Dinu, C.; Ene, C. Distribution of trace metals in surface water and streambed sediments in the vicinity of an abandoned gold mine from Hunedoara County, Romania. Rev. Chim. 2016, 67, 1441-1446.

7. Stancheva, I.; Geneva, M.; Markovska, Y.; Tzvetkova, N.; Mitova, I.; Todorova, M.; Petrov, P. A comparative study on plant morphology, gas exchange parameters, and antioxidant response of Ocimum basilicum L. and Origanum vulgare L. grown on industrially polluted soil. Turk. J. Boil. 2014, 38, 89-102. [CrossRef]

8. Qishlaqi, A.; Farid Moore, F. Statistical analysis of accumulation and sources of heavy metals occurrence in agricultural soils of Khoshk River banks, Shiraz, Iran. Am. Eurasian J. Agric. Environ. Sci. 2007, 2, 565-573.

9. Kabata-Pendias, A. Trace Elements in Soils and Plants; CRC Press: New York, NY, USA, 2001. 
10. Sahito, S.R.; Memon, M.A.; Kazi, T.G.; Kazi, G.H. Evaluation of mineral contents in medicinal plant Azadirachta indica (neem). J. Chem. Soc. Pak. 2003, 25, 139-143.

11. Refaz, A.D.; Mohd, S.; Parvaiz, H.Q. Overview of medicinal plants spread and their uses in Asia. J. Phytopharmacol. 2017, 6, 349-351.

12. Singh, R.; Gautam, N.; Mishra, A.; Gupta, R. Heavy metals and living systems: An overview. Indian J. Pharmacol. 2011, 43, 246-253. [CrossRef]

13. Jabeen, S.; Shah, M.; Khan, S.; Hayat, M. Determination of major and trace elements in ten important folk therapeutic plants of Haripur basin, Pakistan. J. Med. Plants Res. 2010, 4, 559-566.

14. Stanojkovic-Sebic, A.; Pivic, R.; Josic, D.; Dinic, Z.; Stanojkovic, A. Heavy metals content in selected medicinal plants com-monly used as components for herbal formulations. J. Agric. Sci. 2015, 21, 317-325.

15. Asgari Lajayer, B.; Ghorbanpour, M.; Nikabadi, S. Heavy metals in contaminated environment: Destiny of secondary me-tabolite biosynthesis, oxidative status and phytoextraction in medicinal plants. Ecotox. Environ. Safe. 2017, 145, 377-390. [CrossRef]

16. WHO (World Health Organization). Guidelines for Assessing Quality of Herbal Medicines with Reference to Contaminants and Residues; WHO Press: Geneva, Switzerland, 2007.

17. Puri, A.; Kumar, M. A review of permissible limits of drinking water. Indian J. Occup. Environ. Med. 2012, 16, 40-44. [CrossRef]

18. European Commission. Commission Regulation (EC) No 1881/2006 of 19 December setting maximum levels contaminants in foodstuffs. Off. J. Eur. Union 2006, 364, 324-365.

19. Fendorf, S.; Nico, P.S.; Kocar, B.D.; Masue, Y.; Tufano, K.J. Chapter 12-Arsenic Chemistry in Soils and Sediments; Singh, B., Gräfe, M., Eds.; Developments in Soil Science; Elsevier: Berkeley, CA, USA, 2010; Volume 34, pp. 357-378.

20. Igbal, M.; Edyvean, R.G.J. Biosorption of lead, copper and zinc ions on loofa immobilized biomass of Phanerochaete chysosporium. Miner Eng. 2004, 17, 217-223. [CrossRef]

21. Selania, A.; Boukazoula, A.; Kechid, N.; Bakhti, M.Z.; Chergui, A.; Kerchich, Y. Biosorption of Pb (II) from aqueous solution by a bacterial dead Streptomyces rimosus biomass. Biochem. Eng. J. 2004, 19, 127-135. [CrossRef]

22. Yin, J.; Wang, A.P.; Li, W.F.; Shi, R.; Jin, H.T.; Wen, J.F. Sensitive biomarkers identification for differentiating Cd and Pb induced toxicity on zebrafish embryos. Environ. Toxicol. Pharmacol. 2017, 56, 40-349. [CrossRef]

23. Nigam, N.; Khare, P.; Yadav, V.; Mishra, D.; Jain, S.; Karak, T.; Punja, S.; Tandon, S. Biochar-mediated sequestration of Pb and Cd leads to enhanced productivity in Mentha arvensis. Ecotoxicol. Environ. Saf. 2019, 172, 411-422. [CrossRef]

24. Rubio, C.; Lucas, J.; Gutiérrez, A.; Glez-Weller, D.; Marrero, B.P.; Caballero, J.; Revert, C.; Hardisson, A. Evaluation of metal concentrations in mentha herbal teas (Mentha piperita, Mentha pulegium and Mentha species) by inductively coupled plasma spectrometry. J. Pharm. Biomed. Anal. 2012, 71, 11-17. [CrossRef]

25. Huang, D.; Gong, X.; Liu, Y.; Zeng, G.; Lai, C.; Bashir, H.; Zhou, L.; Wang, D.; Xu, P.; Cheng, M.; et al. Effects of calcium at toxic concentrations of cadmium in plants. Planta 2017, 245, 863-873. [CrossRef]

26. Olateju, D.A.; Olalekan, J.K.; Kayode, S.A.; Oluwatosin, G.A. Lead and cadmium contents in a medicinal plant/spice grown an urban city of Nigeria. Cogent Food Agric. 2016, 2. [CrossRef]

27. Dinu, C.; Vasile, G.-G.; Buleandra, M.; Popa, D.E.; Gheorghe, S.; Ungureanu, E.-M. Translocation and accumulation of heavy metals in Ocimum basilicum L. plants grown in a mining-contaminated soil. J. Soils Sediments 2020, 20, 2141-2154. [CrossRef]

28. Susan, A.; Rajendran, K.; Sathyasivan, K.; Krishnan, U.M. An overview of plant-based interventions to ameliorate arsenic toxicity. Biomed. Pharmacother. 2019, 109, 838-852. [CrossRef]

29. Pallottino, F.; Stazi, S.R.; D’annibale, A.; Marabottini, R.; Allevato, E.; Antonucci, F.; Costa, C.; Moscatelli, M.C.; Menesatti, P. Rapid assessment of as and other elements in naturally-contaminated calcareous soil through hyperspectral VIS-NIR analysis. Talanta 2018, 190, 167-173. [CrossRef]

30. Sarkar, A.; Paul, B. The global menace of arsenic and its conventional remediation-A critical review. Chemosphere 2016, 158, 37-49. [CrossRef]

31. Stazi, S.R.; Cassaniti, C.; Marabottini, R.; Giuffrida, F.; Leonardi, C. Arsenic uptake and partitioning in grafted tomato plants. Hort. Environ. Biotechnol. 2016, 57, 241-247. [CrossRef]

32. Shahzad, B.; Tanveer, M.; Rehman, A.; Alam Cheema, S.; Fahad, S.; Rehman, S.; Sharma, A. Nickel; whether toxic or essential for plants and environment-A review. Plant Physiol. Biochem. 2018, 132, 641-651. [CrossRef]

33. Cuiyun, C.; Dejun, H.; Jianquan, L. Functions and toxicity of nickel in plants: Recent advances and future prospects. Clean 2009, 37, 304-313.

34. Blaj, R.; Stanciu, M.; Sand, C.; Barbu, C.H.; Ciortea, G. Pollution effects on forest vegetation and ecological reconstruction in Copsa Mica, Romania. Geoconference on ecology, economics, education and legislation. SGEM Book Ser. Int. Multidiscip. Sci. Geoconf. 2013, 1, 743-750.

35. Dumitrel, G.A.; Popa, M.; Glevitzky, M.; Vica, M.; Todoran, A. Evaluation of soil heavy metal pollution in the Zlatna Region. J Environ. Prot. Ecol. 2013, 14, 1569-1576.

36. Levei, E.; Frentiu, T.; Ponta, M.; Senila, M.; Miclean, M.; Roman, C.; Cordos, E. Characterisation of soil quality and mobility of Cd, $\mathrm{Cu}, \mathrm{Pb}$ and $\mathrm{Zn}$ in the Baia Mare area Northwest Romania following the historical pollution. Int. J. Environ. Anal. Chem. 2009, 89, 635-649. [CrossRef]

37. Dinu, C.; Ungureanu, E.M.; Vasile, G.G.; Kim, L.; Ionescu, I.; Ene, C.; Simion, M. Soil and vegetation pollution from an abandoned mining area situated in Hunedoara County, Romania. Rev. Chim. 2018, 69, 14-20. [CrossRef] 
38. Zheljazkov, V.D.; Craker, L.E.; Xing, B. Effects of Cd, Pb, and $\mathrm{Cu}$ on growth and essential oil contents in dill, peppermint, and basil. Environ. Exp. Bot. 2006, 58, 9-16. [CrossRef]

39. Pandey, J.; Verma, R.K.; Singh, S. Suitability of aromatic plants for phytoremediation of heavy metal contaminated areas: A review. Int. J. Phytoremediat. 2019, 21, 405-418. [CrossRef]

40. Mahmood, M.; Mansour, G.; Khalil, K. Physiological and antioxidative responses of medicinal plants exposed to heavy metals stress. Plant Gene 2017, 11, 247-254.

41. Masarovicova, E.; Kralova, K.; Kummerova, M. Principles of classification of medicinal plants as hyper accumulators or excluders. Acta Physiol. Plant. 2010, 32, 823-829. [CrossRef]

42. Lv, J.; Huang, H.; Yu, L.; Whent, M.; Niu, Y.; Shi, H.; Wang, T.T.; Luthria, D.; Charles, D.; Yu, L.L. Phenolic composition and nutraceutical properties of organic and conventional cinnamon and peppermint. Food Chem. 2012, 132, 1442-1450. [CrossRef]

43. Puiu, D.; Popescu, M.; Niculescu, M.; Pascu, L.F.; Galaon, T.; Postolache, C. Mobility of some high persistent organochlorine compounds from soil to mentha piperita. Rev. Chim. 2019, 70, 278-282. [CrossRef]

44. MAPPM. Ordin 756 al Ministerului Apelor, Padurilor si Protectiei Mediului (MAPPM) Pentru Aprobarea Reglementarii Privind Evaluarea Poluarii Mediului, M. of Romania 303 bis. 1997. Available online: http://biosol.ro/wp-content/uploads/linkuri/ord756-din-03-11-1997-pentruaprobarea-Reglementarii-privind-evaluarea-poluarii-mediului.pdf (accessed on 21 July 2019 ).

45. ISO 11464. Soil Quality. Pretreatment of Samples for Physical-Chemical Analysis; International Organization for Stand-Ardization: Geneva, Switzerland, 2006.

46. ISO 11466. Soil Quality. Extraction of Trace Elements Soluble in Aqua Regia; International Organization for Standardiza-Tion: Geneva, Switzerland, 1995.

47. Vasile, G.G.; Popa, D.E.; Buleandra, M.; David, I.G. An experimental design for the optimization of the extraction methods of metallic mobile fractions from environmental solid samples. Environ. Monit. Assess. 2018, 190, 609. [CrossRef]

48. Lichtenthaler, H.; Buschmann, C. Chlorophylls and Carotenoids: Measurement and Characterization by UV-VIS Spec-Troscopy. In Current Protocols in Food Analytical Chemistry; John Wiley and Sons: New York, NY, USA, 2001; Volume 1, pp. F4.31-F4.38.

49. Krishnan, P.; Ravi, I. Methods for determining leaf chlorophyll content of rice: A reappraisal. Indian J. Exp. Biol. 1996, 34, 1030-1033.

50. Adamczyk-Szabela, D.; Romanowska-Duda, Z.; Lisowska, K.; Wolf, W.M. Heavy metal uptake by herbs. V. Metal accumu-lation and physiological effects induced by thiuram in Ocimum basilicum L. Water Air Soil Pollut. 2017, 228, 334. [CrossRef]

51. Olowoyo, J.; van Heerden, E.; Fischer, J.; Baker, C. Trace metals in soil and leaves of Jacaranda mimosifolia in Tshwane area, South Africa. Atmos. Environ. 2010, 44, 1826-1830. [CrossRef]

52. Kloke, A.; Sauerbeck, D.R.; Vetter, H. The Contamination of Plants and Soils with Heavy Metals and the Transport of Metals in Terrestrial Food Chains. In Changing Metal Cycles and Human Health; Metzler, J.B., Ed.; Springer: Berlin/Heidelberg, Germany, 1984; pp. 113-141.

53. Kastori, R.; Petrovic, N.; Arseniejevic-Maksimovic, I. Heavy Metals and Plants. In Heavy Metals in the Environment; Kastori, R., Ed.; Institute of Field and Vegetable Crops: Novi Sad, Serbian, 2017; pp. 196-257.

54. Allevato, E.; Stazi, S.R.; Marabottini, R.; D'Annibal, A. Mechanisms of arsenic assimilation by plants and countermeasures to attenuate its accumulation in crops other than rice. Ecotoxicol. Environ. Saf. 2019, 185, 109701. [CrossRef]

55. De la Fuente, C.; Clemente, R.; Alburquerque, J.A.; Vélez, D.; Bernal, M.P. Implications of the use of As-rich groundwater for agricultural purposes and the effects of soil amendments on as solubility. Environ. Sci. Technol. 2010, 44, 9463-9469. [CrossRef]

56. Mandal, B.K.; Suzuki, K.T. Arsenic round the world: A review. Talanta 2002, 58, 201-235. [CrossRef]

57. Pigna, M.; Cozzolino, V.; Violante, A.; Meharg, A.A. Influence of phosphate on the arsenic uptake by wheat (Triticum durum L.) irrigated with arsenic solutions at three different concentrations. Water Air Soil Pollut. 2009, 197, 371-380. [CrossRef]

58. Hall, J.L. Cellular mechanism for heavy metal detoxification and tolerance. J. Exp. Bot. 2002, 53, 1-11. [CrossRef]

59. Patel, A.; Pandey, V.; Patra, D. Metal absorption properties of Mentha spicata grown under tannery sludge amended soil-its effect on antioxidant system and oil quality. Chemosphere 2016, 147, 67-73. [CrossRef]

60. Wusheng, J.; Donghua, L.; Wenqiang, H. Hyperaccumulation of cadmium by roots, bulbs and shoots of garlic (Allium sativum L.). Bioresour. Technol. 2001, 76, 9-13.

61. Houri, T.; Khairallah, Y.; Zahab, A.A.; Osta, B.; Romanos, D.; Haddad, G. Heavy metals accumulation effects on the photosynthetic performance of geophytes in Mediterranean reserve. J. King Saud Univ. Sci. 2020, 32, 874-880. [CrossRef]

62. Baruah, S.; Bora, M.S.; Sharma, P.; Deb, P.; Sarma, K.P. Understanding of the distribution, translocation, bioaccumulation, and ultrastructural changes of monochoria hastata plant exposed to cadmium. Water Air Soil Pollut. 2016, 228, 17. [CrossRef]

63. Cuypers, A.; Karen, S.; Jos, R.; Kelly, O.; Els, K.; Tony, R.; Nele, H.; Nathalie, V.; Yves, G.; Jan, C.; et al. The cellular redox state as a modulator in cadmium and copper responses in Arabidopsis thaliana seedlings. J. Plant Physiol. 2011, 168, 309-316. [CrossRef]

64. Mishra, B.; Sangwan, R.S.; Mishra, S.; Jadaun, J.S.; Sabir, F.; Sangwan, N.S. Effect of cadmium stress on inductive enzymatic and nonenzymatic responses of ROS and sugar metabolism in multiple shoot cultures of Ashwagandha (Withania somnif-era Dunal). Protoplasma 2014, 251, 1031-1045. [CrossRef]

65. Hu, J.Z.; Shi, G.X.; Xu, Q.S.; Wang, X.; Yuan, Q.H.; Du, K.H. Effects of Pb2+ on the active oxygen-scavenging enzyme activities and ultrastructure in Potamogeton crispus leaves. Russ. J. Plant Physiol. 2007, 54, 414-419. [CrossRef]

66. Kumar, N.J.I.; Soni, H.; Kumar, R.N.; Bhatt, I. Hyperaccumulation and mobility of heavy metals in vegetable crops in India. J. Agric. Environ. 2009, 10, 34-45. [CrossRef] 
67. Prasad, A.; Singh, A.K.; Chand, S.; Chanotiya, C.S.; Patra, D.D. Effect of chromium and lead on yield, chemical composition of essential oil, and accumulation of heavy metals of mint species. Commun. Soil Sci. Plant Anal. 2010, 41, 2170-2186. [CrossRef]

68. Zheljazkov, V.D.; Nielsen, N.E. Studies on the effect of heavy metals (Cd, $\mathrm{Pb}, \mathrm{Cu}, \mathrm{Mn}, \mathrm{Zn}$ and Fe) upon the growth, productivity and quality of lavender (Lavandula angustifolia Mill.) production. J. Essent. Oil Res. 1996, 8, 59-274. [CrossRef]

69. Chand, S.; Pandey, A.; Patra, D.D. Influence of nickel and lead applied in combination with vermicompost on growth and accumulation of heavy metals by Mentha arvensis Linn. cv. 'Kosi'. Indian J. Nat. Prod. Resour. 2012, 3, $256-261$. 